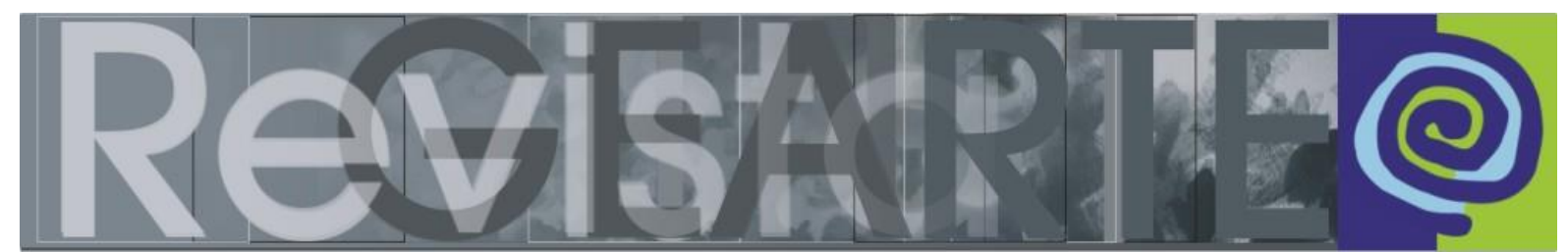

ISSN 2357-9854 | e-ISSN 2596-3198 (online)

\title{
Estudantes de Pedagogia em expedição ao ateliê do artista contemporâneo: encontramos o leão na selva
}

\author{
Lucia Maria Salgado dos Santos Lombardi(i) \\ (Universidade Federal de São Carlos - UFSCar, Sorocaba/SP, Brasil)
}

\begin{abstract}
RESUMO - Estudantes de Pedagogia em expedição ao ateliê do artista contemporâneo: encontramos o leão na selva - $O$ artigo reflete sobre expedições para a galeria/ateliê do artista Ernesto Ferro em Sorocaba, SP, realizadas desde 2013 como parte da formação cultural e artística de pedagogas/os da Universidade Federal de São Carlos. A ação questiona: o que profissionais da Educação podem aprender em expedição ao espaço de trabalho do artista contemporâneo? Verificou-se que são favorecidos os exercícios de apreciação, escuta, observação e imaginação. São ampliadas as possibilidades de exploração de materialidades e de produções atuais que inspiram ações a serem feitas com crianças. É propiciada uma transformação das concepções de arte de futuros/as professores/as.
\end{abstract}

PALAVRAS-CHAVE

Ensino de Arte. Pedagogia. Ateliê. Formação de professores. Arte contemporânea.

\begin{abstract}
Pedagogy students on an expedition to the contemporary artist's studio: we meet the lion in the jungle - The article reflects on expeditions to the artist Ernesto Ferro's gallery/studio in Sorocaba, S.P., carried out since 2013 as part of the cultural and artistic education of pedagogues at the Federal University of São Carlos. The action asks: what Education professionals can learn in an expedition to the contemporary artist's workspace? It was found that the exercises of appreciation, listening, observation and imagination are favored. The possibilities for exploring materialities and current productions that inspire actions to be carried out with children are expanded. A transformation of future teachers' conceptions of art is provided.
\end{abstract}

KEYWORDS

Art teaching. Pedagogy. Studio. Teacher education. Contemporary art.

RESUMEN - Estudiantes de pedagogía en expedición al estudio del artista contemporáneo: encontramos al león en la selva - El artículo reflexiona sobre las expediciones a la galería / estudio del artista Ernesto Ferro en Sorocaba, S.P., realizadas desde 2013 como parte de la formación cultural y artística de pedagogos de la Universidad Federal de São Carlos. La acción pregunta: ¿qué pueden aprender los profesionales de la educación en una expedición al espacio de trabajo del artista contemporáneo? Se constató que se favorecen los ejercicios de apreciación, escucha, observación e imaginación. Se amplían las posibilidades de explorar materialidades y producciones actuales que inspiran acciones a realizar con niños. Se proporciona una transformación de las concepciones del arte de los futuros profesores.

\section{PALABRAS CLAVE}

Enseñanza del arte. Pedagogía. Estudio. Formación de profesores. Arte Contemporaneo. 


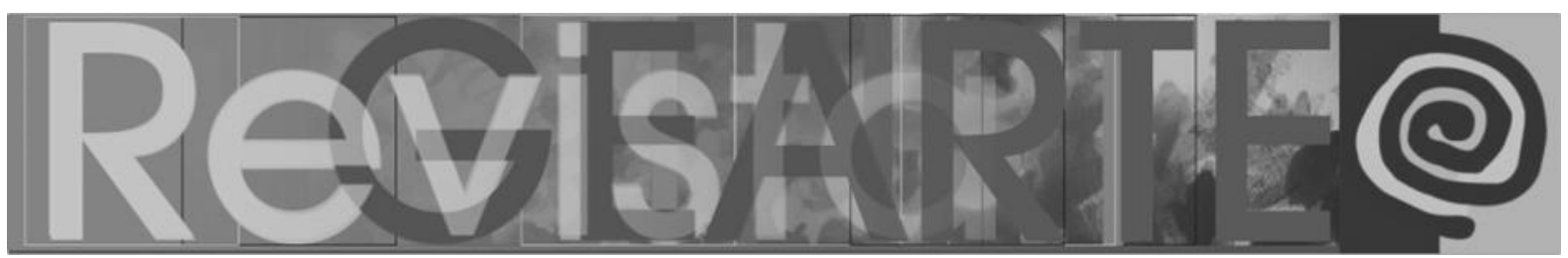

Beta Germano (2019, p. 19) conta que o crítico de arte Ronaldo Brito costuma dizer que "o artista no ateliê é como o leão na selva e o artista no museu é como o leão no zoológico". A metáfora explicita os motivos pelos quais a entrada no espaço de isolamento do artista provoca fascínio. É a entrada nessa selva que aqui se apresenta, por meio de expedições artísticas para o híbrido galeria/ateliê do artista Ernesto Ferro, de Sorocaba, cidade a 100,8 km de distância da capital do Estado de São Paulo. Desde 2013, elas têm sido realizadas como parte da formação cultural e artística de futuras/os pedagogas/os, no âmbito da disciplina Metodologia do Ensino de Arte, do curso de Licenciatura em Pedagogia da Universidade Federal de São Carlos campus Sorocaba (UFSCar).

Sendo necessário compreender mais profundamente os elementos envolvidos nessa ação de aprendizagem das artes, é elaborada a questão: o que profissionais da Educação podem aprender em expedição ao espaço de trabalho do artista contemporâneo?

O texto inicia-se abordando duas dimensões de grande importância na formação de pedagogos/as, profissionais que podem atuar em diversos espaços da área de Educação, sobretudo na docência na Educação Infantil, nos anos iniciais do Ensino Fundamental e nas disciplinas pedagógicas para a formação de professores/as, bem como na gestão educacional: a educação de crianças e a nutrição estética. Em um segundo momento, a fim de alinhavar os valores apresentados à ação prática desenvolvida, apresenta-se como a expedição ao ateliê acontece, discorrendo-se sobre o que é o ateliê do ponto de vista histórico, sua função e atuais possibilidades de desdobramentos; sobre Ernesto Ferro e sua produção; sobre como a expedição é realizada desde o pré-campo, partindo para a apreciação das obras no ateliê/galeria, o bate-papo com o artista, a oficina de experimentação criativa conduzida por ele e, por fim, as reflexões feitas após a ação. 


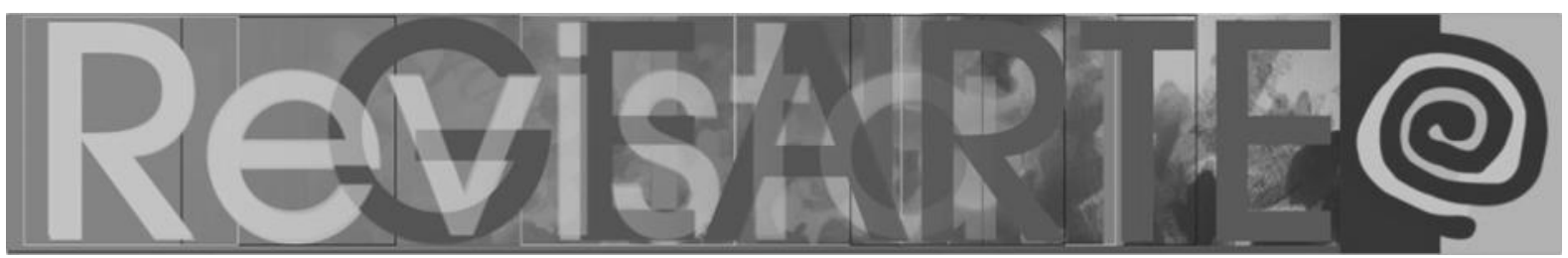

A educação de crianças e a nutrição estética: princípios não perecíveis ao ensino de Arte e à Pedagogia

O que nos leva, como professores/as, à necessidade de nos alimentarmos culturalmente, de conhecermos mais arte e mais artistas - longínquos e dos arredores da própria comunidade - para além do que propõem os meios massivos de comunicação? A problemática é ampla e complexa, mas um ponto de partida consistente é compreender que a riqueza de experiências e referências artísticas afeta o desempenho de professores/as como mediadores/as culturais.

As expedições artísticas são realizadas com base em princípios fundantes dos campos da Pedagogia e da Arte/Educação, entre os quais destaco dois, imbricados no processo de formação de pedagogos/as. Primeiramente, está o compromisso de atuação ética, política e estética na prática pedagógica com bebês e crianças pequenas (BRASIL, 2010), estando os/as pedagogos/as entre os/as primeiros/as mediadores/as culturais da vida das crianças. Isto leva ao segundo princípio, relacionado à importância da ampliação dos repertórios culturais de futuros/as professores/as por meio do ensino de Arte ${ }^{1}$. Esses pontos de vista são delineados a seguir.

Ter a criança como foco: a criança reivindica para si a liberdade de imaginar, brincar, experimentar e ter uma boa surpresa por dia!

Um princípio essencial que une os campos da Arte e da Pedagogia na formação artística de professores/as é o compromisso de atuação do/da pedagogo/a como um/a dos/das primeiros/as mediadores/as culturais da vida das crianças nas escolas, complementando a educação das famílias, reconhecendo as especificidades e a diversidade das diferentes infâncias.

No Brasil, o curso de licenciatura em Pedagogia é o que forma professoras/es para trabalhar na Educação Infantil, primeira etapa da educação básica, oferecida em creches - para crianças de zero a 3 anos e 11 meses - e pré- 


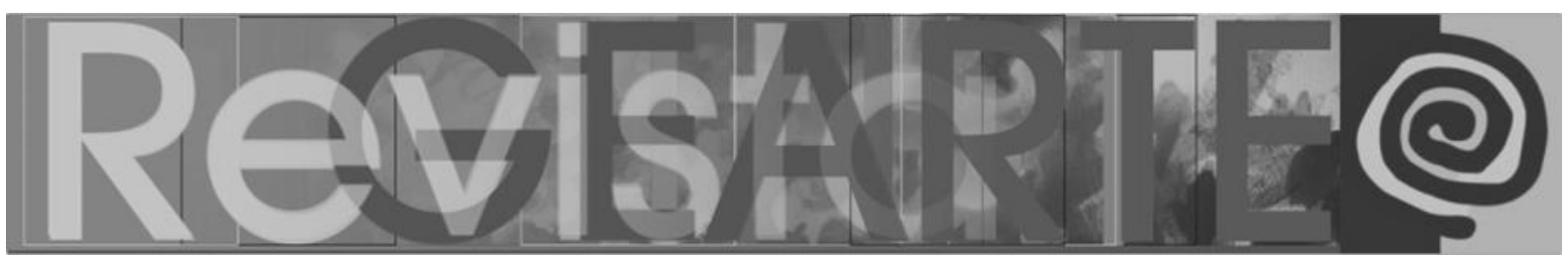

escolas - para as crianças de 4 anos a 5 anos e 11 meses - e nos Anos Iniciais do Ensino Fundamental. A Educação Infantil é um direito social de todas as crianças sem que se faça distinção de origem geográfica, fenótipo, etnia, sexo, deficiência física ou mental, nível socioeconômico, religião.

O/A profissional da Educação formado/a pelo curso de Pedagogia trabalha em espaços escolares, em espaços não escolares, na gestão das instituições e, em caso de atuar na docência, deve ensinar diversas disciplinas de forma interdisciplinar e adequada às diferentes fases do desenvolvimento humano (BRASIL, 2006). Então, o contexto do qual tratamos não é o de formação de artistas, mas sim de educadores/as que precisam de conteúdos e experiências pensadas especialmente para eles/as, permitindo-lhes acesso a percursos artísticos e poéticos que mobilizem compreensões sobre modos de trabalhar com as artes em diferentes faixas etárias e contextos sociais, estranhando antigos hábitos pedagógicos (MARTINS; LOMBARDI, 2017).

De fato, uma dimensão norteadora da formação artística de pedagogos/as é ter a criança como foco. Ser pedagogo/a significa se posicionar no lugar de fala da criança, falando com e para ela, em defesa dela, considerando-a como centro de sua proposta pedagógica, protagonista do processo educativo, combatendo modos pedagógicos transmissivos, pensando a criança como ser participante, e não como um ser em espera de participação (OLIVEIRA-FORMOSINHO, 2007).

Um dos compromissos dessa profissão é o respeito pelos bebês e pelas crianças pequenas de diversos contextos em relação às suas necessidades específicas, entre as quais está a de ser respeitada como criança - em sua condição vital de ser simultaneamente dependente dos cuidados do adulto $\mathrm{e}$ independente em seus processos interativos no mundo (RICHTER; BARBOSA, 2010).

Ao pensar sobre isso, Faria (1999) e Faria, Macedo e Santos (2013) afirmam que o fato de a criança não falar, não escrever ou não saber fazer as coisas que 


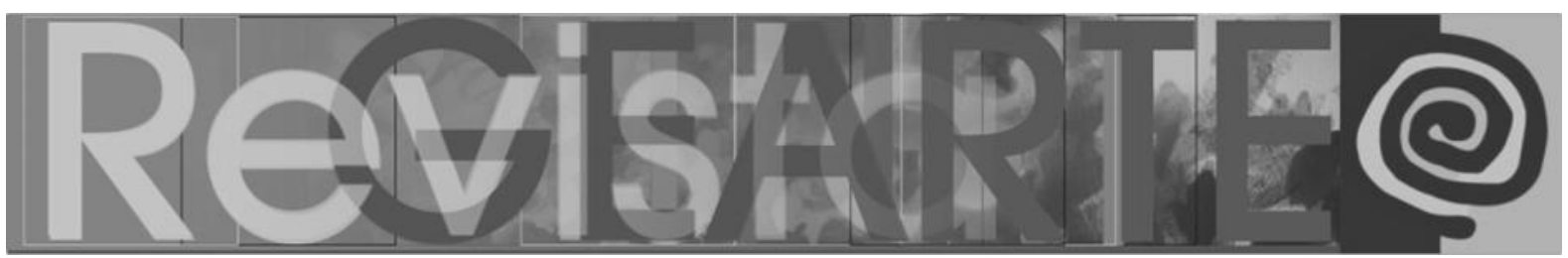

fazem os adultos, que são comumente consideradas características de ausência, incoerência ou precariedade, é justamente o que a transforma em produtora de cultura infantil, pois, em vez de ser "falta" ou incompletude, é, exatamente, a infância. As autoras afirmam que a Pedagogia como ciência tem as crianças pequenas como protagonistas, que criam culturas, e não unicamente internalizam conhecimentos dos adultos, e que têm direito de viver o seu presente.

Refletindo sobre os direitos de aprendizagem das crianças, Olga Egas (2015) entrelaça os seus pensamentos aos de Fernando Bonassi em "Declaração universal do moleque invocado", para afirmar que a criança reivindica para si a liberdade de imaginar, brincar, experimentar e ter uma surpresa por dia, significando que trabalhamos para que a infância possa ser plena em experiências e afetos, apesar da indignação diante da constatação de que nem todos os meninos e meninas vivenciam assim a infância.

Sendo mediadoras de aprendizagens, de brincadeiras, de linguagens expressivas e garantindo seu direito à confiança e à dignidade, as professoras compreendem que a surpresa na vida da criança acontece por meio de sua capacidade exploradora, inventiva e curiosa. Se Ihe for concedida a possibilidade de participação em propostas com as artes, os jogos infantis, os ambientes, os materiais, a espontaneidade emerge nos gestos sensíveis: então, a criança se surpreende e nos surpreende. A criança é capaz de maravilhamentos.

No trabalho pedagógico desenvolvido para e com elas, respeitá-las significa também se fazer capaz de ver o mundo do seu ponto de vista, inclusive escutando o bebê ou a criança bem pequena que ainda não fala por meio de palavras. Desde o nascimento, o ser humano faz uso de uma linguagem pré-verbal a fim de manifestar-se e, portanto, a professora de bebês, levando em conta outras possibilidades expressivas que não somente a fala por palavras, cria um ambiente favorável à compreensão mútua, por meio de um diálogo que entende o que os bebês falam por meio da linguagem expressiva do corpo (LOMBARDI, 2011). 


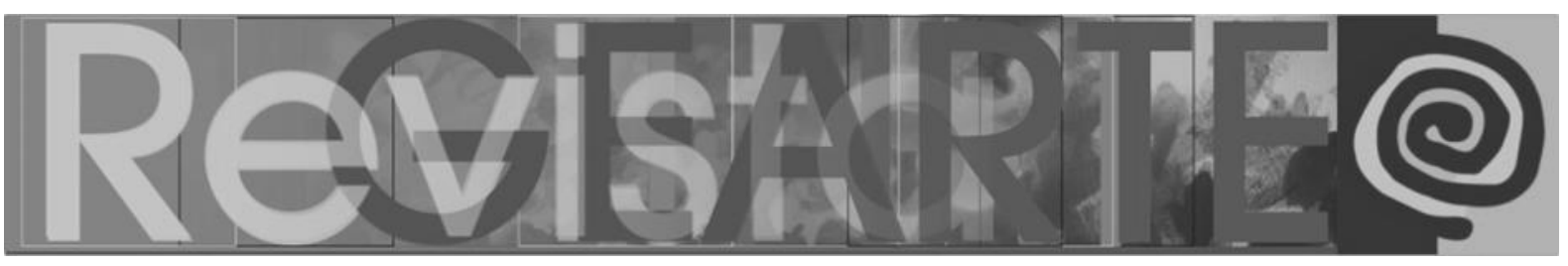

Faz parte da formação acadêmica em Pedagogia aprender a respeitar a criança de forma a educá-la e cuidá-la combatendo os diversos tipos de violência, subordinação e desumanização, as formas de colonialismo que se estabelecem por meio de relações de poder, tais como o racismo, o adultocentrismo, a homofobia, o machismo, desde as primeiras relações em espaços coletivos de educação, em busca de uma pedagogia descolonizadora (FARIA; MACEDO; SANTOS, 2013; MACEDO; SANTIAGO; SANTOS; FARIA, 2016).

Estamos, portanto, em um território que apresenta como especificidade a necessidade de aproximação com as crianças, com as culturas infantis e com a pesquisa sobre modos de realizar o trabalho pedagógico com as linguagens artísticas junto a elas. A criança precisa viver múltiplas experiências de contato com o mundo para aprender. E para ser capaz de planejar, executar e refletir sobre ações de exploração das crianças, o/a futuro/a professor/a precisa também vivenciar as linguagens expressivas em seu processo de formação. Somos mais inventivas/os na medida em que temos repertório mais enriquecido.

\section{A nutrição estética abastece o repertório cultural docente para dialogar com as realidades}

Alimentamo-nos de arte ao produzi-la, ao estudar sobre ela e ao apreciá-la. Por meio da fruição de expressões de diferentes povos, fazemos crescer o conjunto de nossos conhecimentos de mundo, ampliando nossos repertórios e horizontes de pensamentos. Isso torna a experiência de fruir formas artísticas fundamental ao processo de formação docente. Afinal de contas, em se tratando do campo da formação de professores/as, gozamos hoje da compreensão de que a preparação cultural é imprescindível para o cumprimento da função profissional docente de enriquecer culturalmente os/as estudantes nas escolas. Em outras palavras, para que um/a professor/a possa ser mediador/a de conhecimentos, ele/ela precisa ter tido acesso ao patrimônio historicamente construído pela humanidade, bem como precisa manter constante a alimentação de seus 


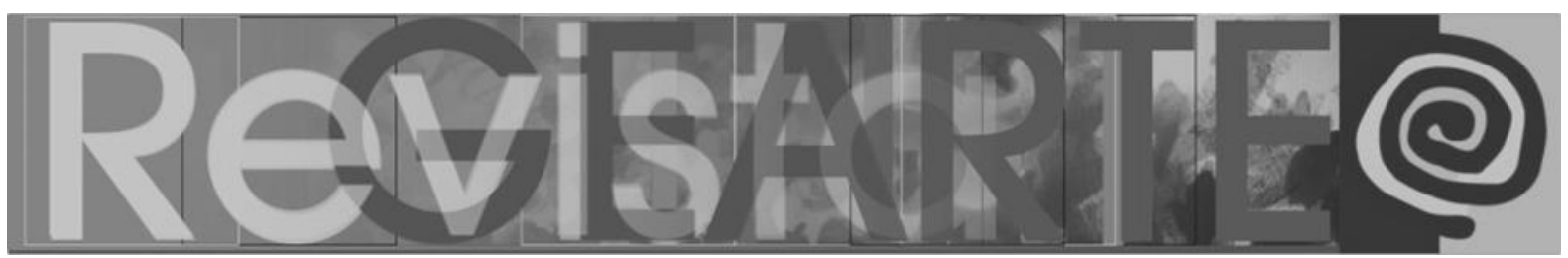

referenciais culturais. É por isso que se atribui à universidade a tarefa de formar professores/as em conhecimentos culturais e científicos, conectados à atitude investigativa e crítica.

Apreciar arte é um ato de nutrir-se esteticamente. Nesse sentido, na década de 1980, ganhou contorno o termo "nutrição estética", no contexto de uma disciplina ministrada por professoras de Arte de São Paulo - Mirian Celeste Martins (Artes Visuais), Sandra Chacra (Teatro), Cecília Tucuri, Célia Galhano e Marina Célia Moraes Dias (Música) -, evidenciando a importância da atribuição de sentidos e significados ao ato da fruição. Em momento de nutrição estética, obras de arte, poesias, fragmentos de filmes, imagens, trabalhos de crianças ou jovens alimentam olhares, percepções, pensamentos no encontro sensível com a arte, recriando a aventura de olhar o mundo por uma perspectiva singular (MARTINS; AMERICANO, 2018).

Propiciar tempos de nutrição estética com apreciação de arte é uma ação pedagógica que objetiva contribuir com a ampliação de repertórios de futuros/as professores/as e que parte de um posicionamento bastante definido em relação ao debate sobre democratização do acesso aos bens culturais. Quando se coloca em suspeita quem tem direito ou não tem direito de consumir arte, quem pode fruir música, teatro, dança, pintura, cinema, poesia, performance, nossa tarefa é reafirmar que arte é "linguagem expressiva das formas sensíveis e subjetivas que compõem a humanidade" (EGAS, 2015, p. 121), que dá às coisas sentido poético e ampliado. Arte é conhecimento e, sendo assim, patrimônio a ser apropriado por todas as pessoas, como parte do processo de construção das identidades e da cidadania. Professores/as, portanto, têm direito à formação cultural e artística.

Pesquisadores como Imbernón (1997) e Sacristán (1999) enfatizaram a importância da formação cultural de professores/as. O "conhecimento cultural", o qual incorpora o interesse pela cultura em suas diversas manifestações e formas artísticas, é tido por Imbernón (1997) como um tipo de conhecimento importante 


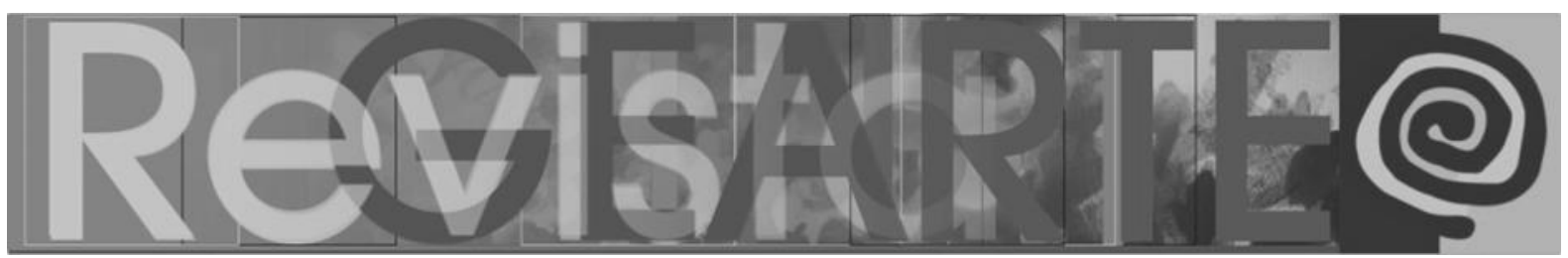

para a prática reflexiva e para a formação e para o desenvolvimento profissional. Sacristán (1999) ressaltou a concepção do professor como mediador que aproxima os estudantes do mundo da cultura e, por isso, para poder ensinar, precisa ele mesmo possuir cultura em profundidade, caso contrário, não poderá ensiná-la nem em níveis elementares.

Ainda que fruição pressuponha conhecer, é possível atribuir maior significado à apreciação da produção de artistas quando mergulhamos em seus elementos constitutivos e nos colocamos em situação de experiência. Articular o fruir, o contextualizar e o fazer (não necessariamente nessa ordem) como dimensões intimamente relacionadas entre si de forma dinâmica e retroalimentadora (PIMENTEL, 2017) potencializa a aprendizagem da arte.

Nesse sentido, as vivências aqui apresentadas - de expedições com estudantes do curso de Pedagogia para a galeria/ateliê de um artista da cidade onde a universidade se localiza - inspiram-se na fecundidade da Abordagem Triangular, elaborada no final dos anos 1980 pela pesquisadora Ana Mae Barbosa, disseminada por todo o Brasil e com reconhecimento internacional, que entrelaça os eixos do fazer, do fruir e do contextualizar nos processos de ensino e aprendizagem das linguagens artísticas.

Desde que foi sistematizada, a Abordagem vem passando por reformulações e aprofundamentos, mas permanece concebendo as artes como expressão e cultura, em consonância com as perspectivas contemporâneas. Inicialmente apresentada no livro $A$ imagem no Ensino da Arte: anos 80 e novos tempos (1991), ao longo dos anos de experimentação, "vem sendo aprimorada tanto a partir das pesquisas que a observam na prática quanto a partir de pesquisas que procuram se aprofundar nos âmbitos teóricos e epistemológicos" (RIZZI; SILVA, 2017, p. 220). A própria Ana Mae Barbosa vem aperfeiçoando o que ela mesma sistematizou, como por exemplo quando realizou adequação terminológica e alteração do eixo "História da Arte" para "contextualização" (BARBOSA, 1998) e 


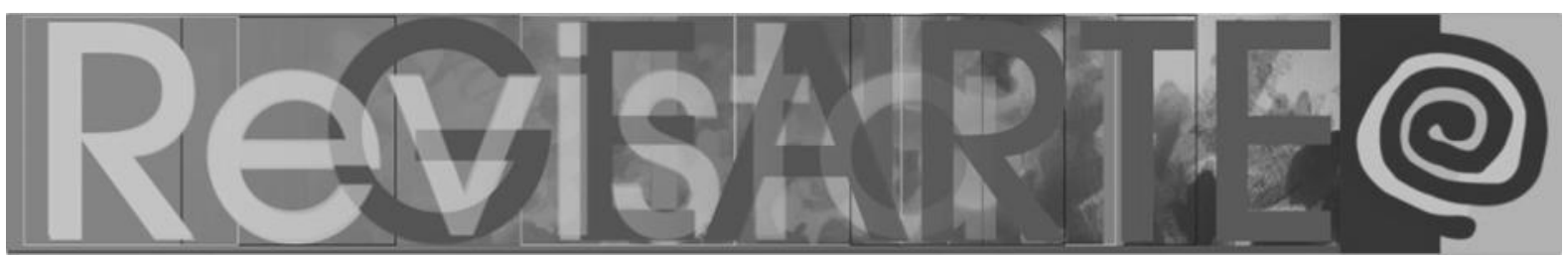

explicitação da abordagem teórico-política de temas contemporâneos (BARBOSA, 2002).

Tomando como referência essa abordagem, as expedições fazem parte da dimensão do fruir/apreciar. Entretanto, considerando que elas acontecem em um processo de formação docente, são planejadas de forma a também envolver os fazeres, isto é, os momentos de criação na oficina ofertada pelo artista no ateliê, bem como o investigar sobre a arte contemporânea nas aulas que precedem o encontro. Como a integralidade do ensino de Arte se dá com base na articulação entre esses três eixos basilares, a expedição, do modo como é feita, resulta em uma "combinação articulada do conjunto das ações (ler, contextualizar e fazer)" (RIZZI, 2008, p. 346).

\section{Como a expedição acontece: o que é esse lugar? Quem é o artista? Como é} feita? Ateliês de artistas são ilhas de liberdade

"Os ateliês dos artistas são ilhas de liberdade. Devemos protegê-los e descobrir formas de manter sua existência", afirma Pablo León de la Barra (2019, p. 13). Por que e como esse espaço se torna um espaço de liberdade? O que é o ateliê?

Junqueira e Gomes (2009) afirmam que as transformações que o ateliê do artista sofreu ao longo da história da arte foram intensas, em especial a partir da década de 1960, com a expansão das linguagens artísticas e da influência da arte conceitual. Ticoulat (2019) explica que, a partir dessa década, a arte rompeu com suas molduras e foi para a rua, adaptando a função do ateliê a novos parâmetros e condições do fazer artístico, novas linguagens, como a performance, a instalação, a videoarte. Ticoulat (2019, p. 25) afirma:

Tal movimento levou à ideia de uma produção "pós-estúdio", ou seja, a criação se dando fora do ateliê, sem sua estrita necessidade. No entanto, ele nunca foi embora, e continuou sendo constantemente reinventado em resposta às realidades sociais e tecnológicas que se apresentavam. $\mathrm{O}$ antigo local de criatividade solitária e exploração de materiais transformou-se em um espaço social e profissional, verdadeiro campo de força do artista contemporâneo. 


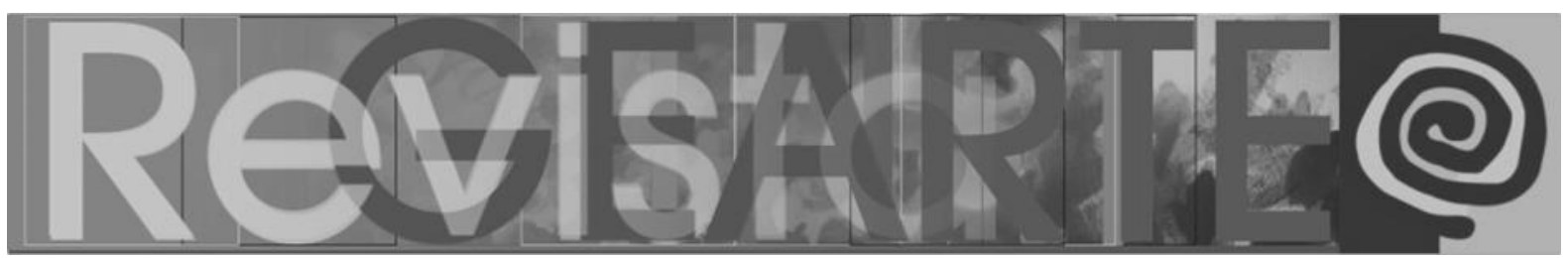

Ao pensarem sobre qual seriam a função e as possibilidades de desdobramentos do ateliê hoje, considerando a trajetória histórica desde a noção clássica de ateliê como espaço físico de trabalho do artista e de ensino de suas práticas, Junqueira e Gomes (2009) afirmam que ele é reconhecido como um espaço de grande importância para a produção cultural e a educação desde o Renascimento, quando Leonardo da Vinci, no Cinquecentto, abria seu ateliê para reuniões de artífices amadores sob orientação científica, dando origem, possivelmente, à primeira academia. A partir do século XVIII, quando as academias oficiais do Estado lideravam o ensino das artes, elas o faziam filiandose também a ateliês e ao museu.

Ao longo do século XX, a noção do ateliê como lugar exclusivo de produção artística foi sendo transformada por trabalhos que criavam fusões entre esfera pública e privada, entre arte e vida, sendo que este lugar de trabalho do artista foi deixando de ser local de isolamento, "reduto do exercício de liberdade total do artista sob suas criações, algo que o apartaria da sociedade durante a criação da obra..." (JUNQUEIRA; GOMES, 2009, p. 2070), passando a ser visto “... como um espaço de cruzamento de subjetividades múltiplas, no qual a obra é construída também pelo espectador" (JUNQUEIRA; GOMES, 2009, p. 2070).

O ateliê passa a ser um lugar no qual as ações podem acontecer com caráter coletivo, em conexões com outros espaços, aliando forças para viabilizar o trabalho do artista, a difusão cultural, a formação artística da comunidade. Entre as terminologias mais correntes atualmente para designar a existência desse “espaço físico”, segundo Nunes (2013, p. 46), estão as seguintes:

Centro, Espaço, Lugar, Dispositivo, Iniciativa, Zona, Casa, Galeria, Sala, Associação, Fundação, Agência, Território, Plataforma, Ateliê, Projeto, Organismo e Estúdio. Em alguns casos, antes ou depois de um nome próprio, como '397', 'Rés-do-Chão', 'EXA', 'Xiclet', 'Poste', há um adjetivo ou uma descrição que procura absorver e esclarecer um tipo de tática, de formação ou de característica destes espaços, como: 'Autogestionada(o)', 'Autodependente', 'Co-dependente', 'Autônoma(o)', 'Independente', 'Interdependente', 'Polivalente', 'Experimental', 'Artística(o)', 'Alternativa(o)' e 'Cultural'. 


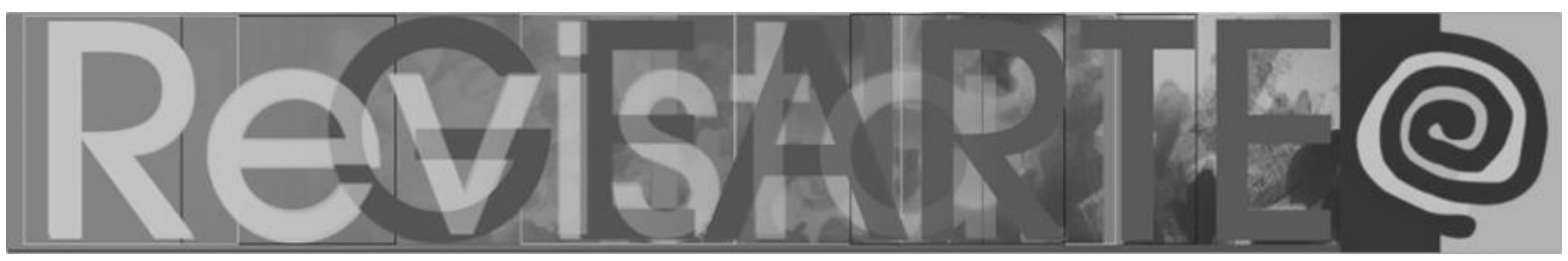

Ernesto Ferro, até o momento, preferiu não definir nomes para sua selva. Do ponto de vista da universidade, denominamos o espaço como "Galeria Ernesto Ferro", território que vem sendo protagonista na esfera da formação cultural e artística de professores/as, como dispositivo de fruição, criação, debate e socialização artística. É um lugar que promove grande fortalecimento do direito das pessoas de acesso à cultura contemporânea e de ampliação do repertório estético de profissionais da Educação.

As expedições de estudantes do curso de Pedagogia ao ateliê/selva de Ernesto Ferro acontecem porque ele aceitou abri-lo para que pudéssemos entrar, mediante meu pedido. Lugar de gestação, de criação, onde o mundo é processado pelo artista antes de retornar ao mundo como obra de arte; espaço de solidão e liberdade; lugar de dúvida, de erros e enganos que às vezes se tornam a obra (DE LA BARRA, 2019), o ateliê passa a ser investigado como espaço de compartilhamento, de trocas e aprendizados em interface com a cidade e seus sujeitos.

Apesar de o espaço de Ernesto Ferro ser um híbrido galeria/ateliê - pois foi pensado para possibilitar reconfigurações que Ihe permitam também ser dedicado a exposições e divulgações de seu trabalho -, visitas regulares de estudantes passaram a acontecer de forma efetiva a partir de 2013, com a parceria entre a universidade $\mathrm{e} o$ ateliê, que vem se estabelecendo como uma cumplicidade afetiva, educacional e artística. As visitas acontecem como um tempo de nutrição estética fora do campus universitário, em conjunto com os outros eixos que compõem a disciplina Metodologia do Ensino de Arte, os quais objetivam descobrir quais as possíveis relações entre a arte contemporânea e a formação de futuros/as pedagogos/as.

Atuando de forma independente, isto é, com recursos próprios, Ernesto Ferro busca modos de diálogo com a cidade. Ele parece ter o desejo de espalhar saberes da selva, derrubando as paredes do ateliê, não somente por receber 


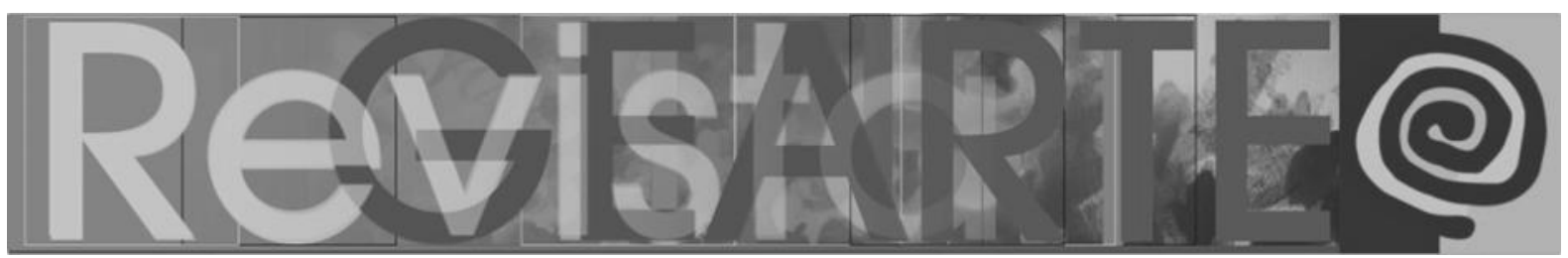

pessoas nesse lugar e expor seus trabalhos em espaços museológicos tradicionais, mas também indo para o espaço urbano, performando nas ruas, iluminando no cotidiano da comunidade o valor das artes integradas que produz. Nesse sentido, seu local de trabalho pode ser entendido como um "ateliê aberto", lugar de liberdade que contribui com o repensar do ofício e dos modos de vinculação de expectadores/as críticos/as.

Sua galeria/ateliê começa na rua. Na calçada se avista o muro performático que provoca a interrupção da caminhada e o olhar para uma arte, uma ideia que suspende a rotina. $\mathrm{O}$ artista muda a fachada a cada quinze dias, instalando frases e obras de arte, que correm o risco de serem roubadas ou, como prefere dizer o artista, "apropriadas" por alguém. Atravessando a fachada se adentra o espaço expositivo, que comporta o acervo do artista, onde exposições são promovidas. Esse grande salão que tem ligação com uma ampla varanda e um quintal permite muitas reconfigurações, tomando função de ateliê para as criações próprias e oficinas de arte, já que todas as suas estruturas são móveis, pensadas e construídas pelo próprio artista.

\section{Quem é o artista?}

Ernesto Ferro nasceu em São Paulo em 1965. Sua mãe ajudava a família em um pensionato que recebia imigrantes, onde conheceu um escultor espanhol, que viria a ser pai do artista. Exerceu o ofício da marcenaria até 2010 e, paralelamente, criava suas obras. Cursou Bacharelado e Licenciatura em História, Técnico em Design e em 2019 concluiu o Bacharelado em Filosofia na Universidade Estadual Paulista (UNESP) campus Marília. Até o momento de encerramento deste texto, participou de 24 exposições individuais, 13 exposições conjuntas, tendo sido premiado em 20 salões e mostras de arte dos 28 em que foi selecionado.

Sua produção se dá partindo da escultura e adentrando outras manifestações das Artes Visuais, da instalação e da intervenção urbana. Se posso compreender, a partir das conversas com o artista e da apreciação de seu trabalho, 


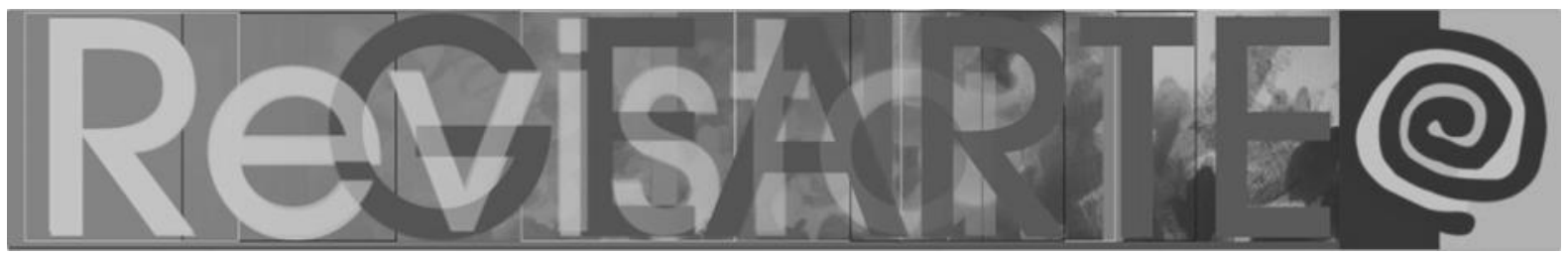

que há algum elemento detonador ou gerador de possibilidades de suas obras, este seria o ser humano embrenhado na tensão da vida social. Essa característica bastante marcante de seu trabalho pode ser observada, por exemplo, na produção de cadeiras fraturadas, as quais the servem para compor diversas obras da série FRATURAS, que é um ensaio filosófico que trata das relações humanas no mundo pós-moderno, sociedade fraturada e fragmentada, sociedade líquida. Para Ernesto Ferro, a cadeira é um ícone representativo do ser, a qual ele apresenta totalmente fraturada e envolta em ataduras que tentam inutilmente cobrir e recuperar as máculas e os ferimentos causados por esse trilhar. Não por acaso, as peças esboçam um movimento rastejante e sofrível e aparecem em diversas obras do artista, inclusive em intervenções urbanas. Isso de sermos um corpo social que se faz no convívio move sua pulsão criativa muito antes do que do pensamento sobre o produto que vai nascer de suas inquietações.

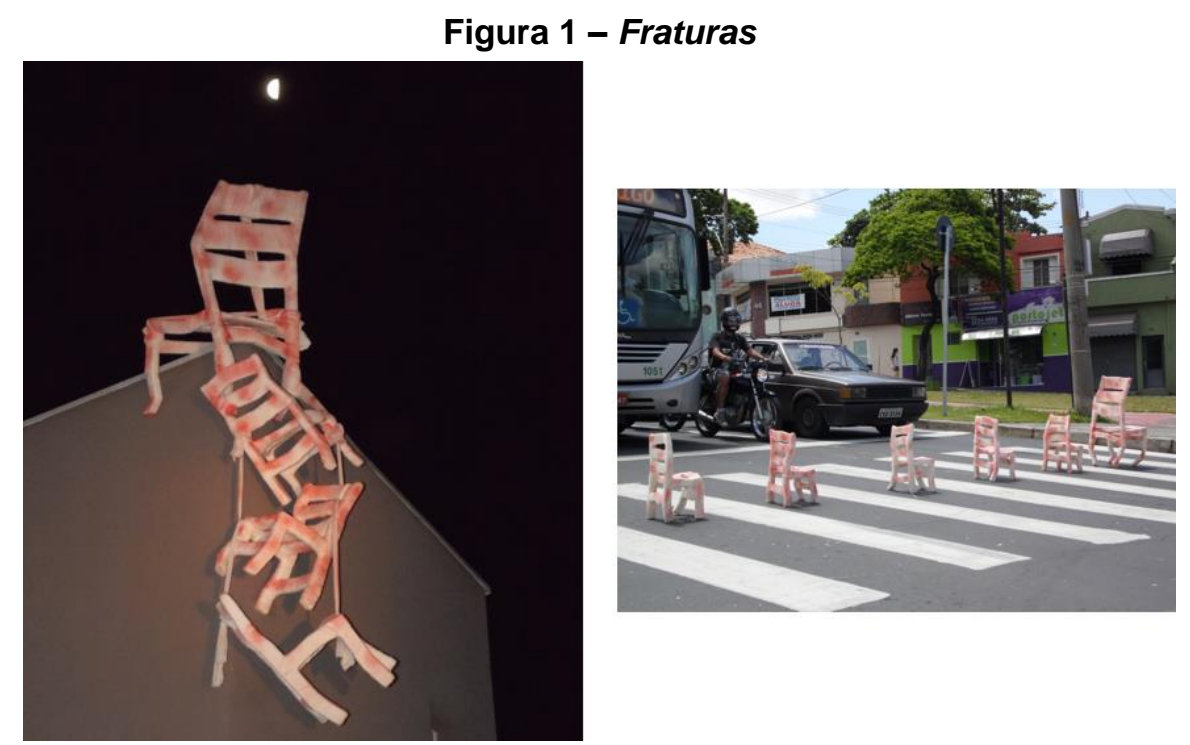

Fonte: Ernesto Ferro, 2016.

FRATURAS já foi levada a diversas localidades, inclusive ao campus Sorocaba da UFSCar, no formato de uma sala de aula tradicional. Instalada no meio do caminho que professores/as e estudantes percorrem para chegar aos prédios de salas de aula, questionou padrões cristalizados da cultura escolar, convidando a possíveis transformações do cenário. 


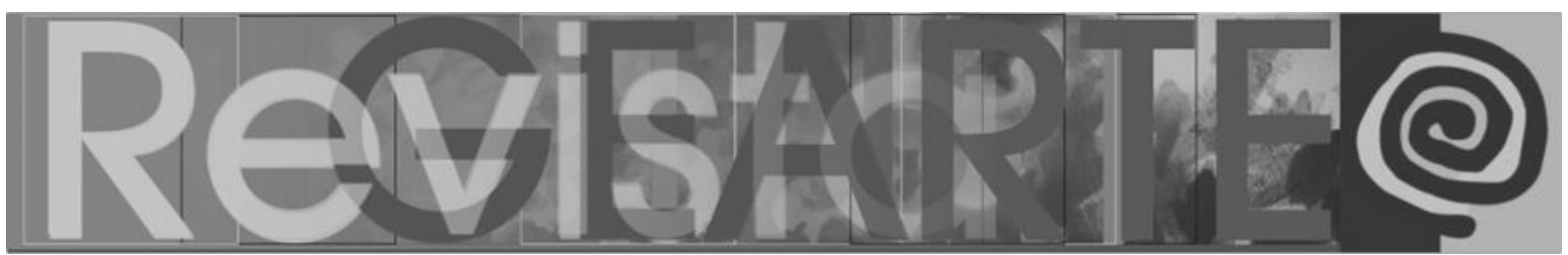

Em 2012, iniciou a série de esculturas Viagens orgânicas, a qual gera a mostra Delírios da forma. Esta série conta atualmente conta com 48 peças, feitas a partir de blocos de lâminas de madeira prensada. Mais que uma simples matéria, a madeira é vista por Ernesto como um elemento facilitador para a constante descoberta de novas possibilidades de expressão, permitindo total interatividade com outros materiais.

Figura 2 - Algumas peças de Viagens Orgânicas, na galeria Ernesto Ferro

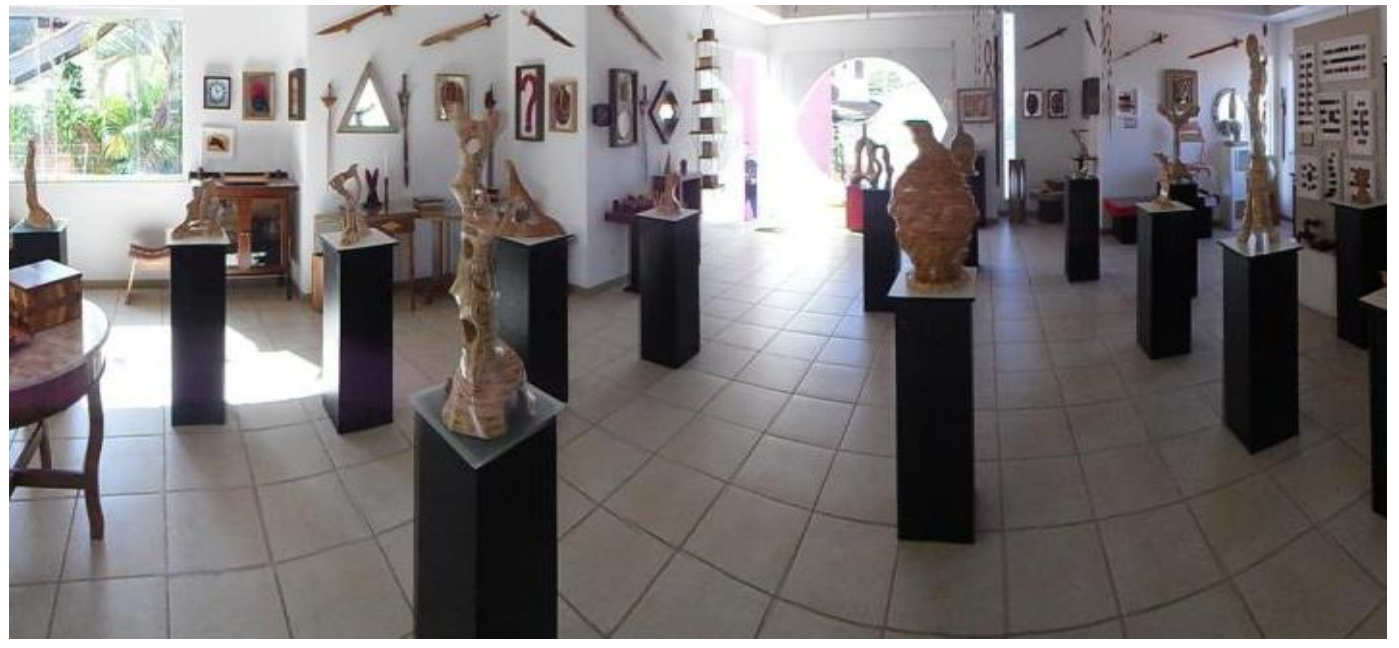

Fonte: Ernesto Ferro, 2015.

Seus trabalhos buscam aproximar a dimensão sensorial e a conceitual um pouco mais além dos limites da forma e da cor. Seu livro Instante Reflexo (FERRO, 2013), premiado no Concurso Literário da Secretaria de Cultura de Sorocaba, em 2014, na Categoria Ensaio Científico, levou o mesmo nome da coletânea de trabalhos sobre a condição humana e o tempo atual, tendo como ícone principal a cadeira, representando o ser humano. Ernesto ${ }^{2}$ afirmou em entrevista concedida para mim em março de 2014:

A simplicidade das obras se perde na absurdidade a que elas remetem. Convida o expectador a experimentar sensações que vão além da forma e da cor, fazendo-o interagir com os conceitos propostos. Inútil tentativa de poetizar o que é perturbador e insustentável, mas sempre priorizando e valorizando o possível, pois é na experimentação plena daquilo que somos que sentimos o quanto ainda devemos crescer. (informação verbal) 


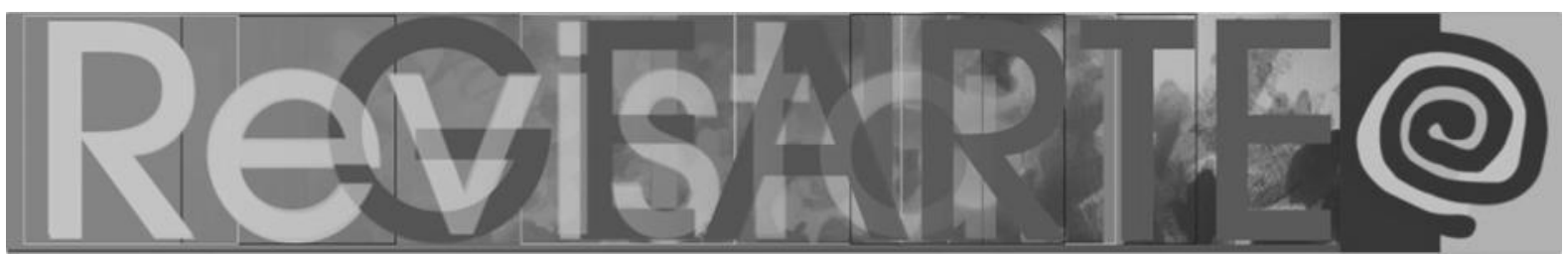

Continuando a falar sobre seu trabalho, ele relata que a coletânea de trabalhos conceituais denominada Instante Reflexo: conceitos do absurdo faz uma abordagem subjetiva da condição humana e do tempo atual. $\mathrm{O}$ ícone usado para representar o ser é a cadeira. Materializa a figura de um determinado tempo, não como fenômeno de sequência de instantes, mas de um tempo histórico no qual o homem vem perdendo a noção da existência.

Figura 3 - Ausente Porvir, da coletânea Instante Reflexo: conceitos do absurdo

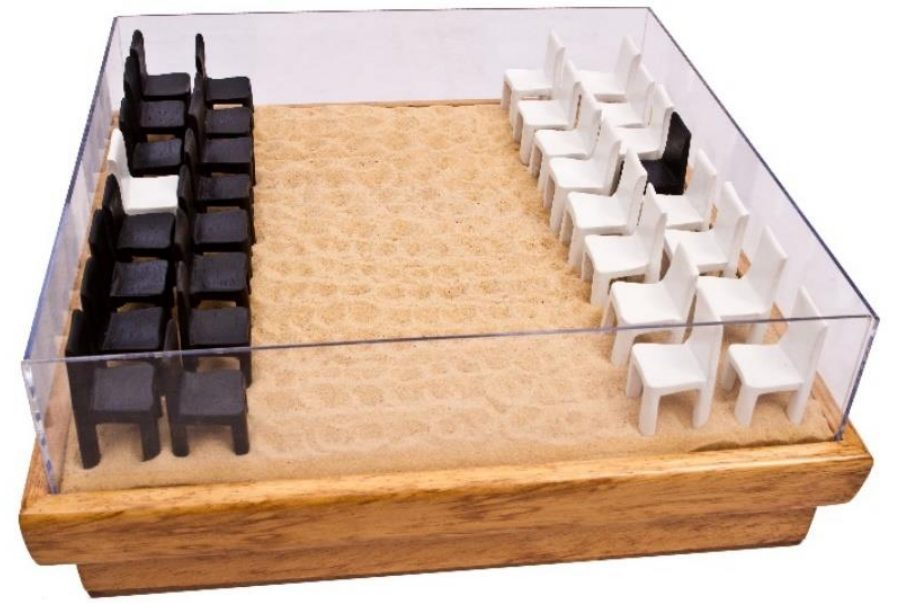

Fonte: Ernesto Ferro, 2013.

Figura 4 - Instante Reflexo, da coletânea Instante Reflexo: conceitos do absurdo

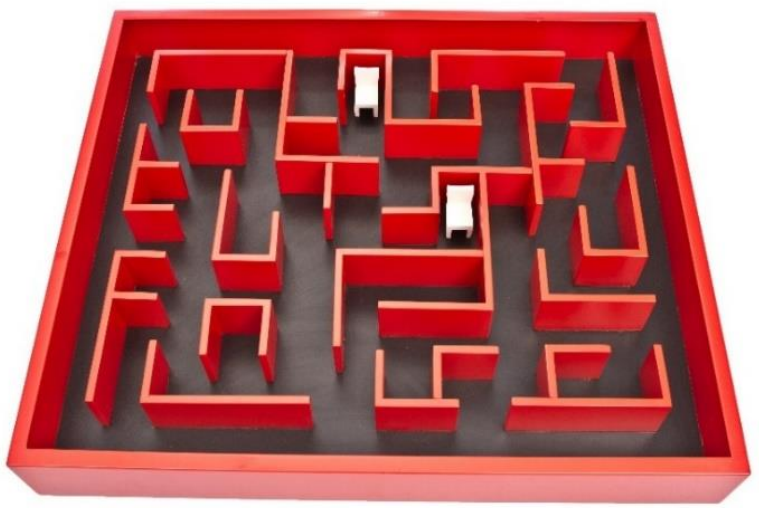

Fonte: Ernesto Ferro, 2009. 


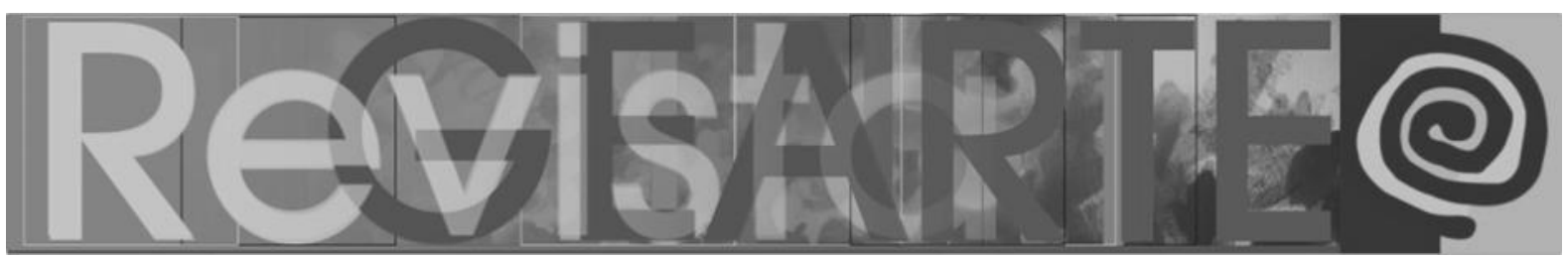

Figura 5 - Espera I., da coletânea Instante Reflexo: conceitos do absurdo

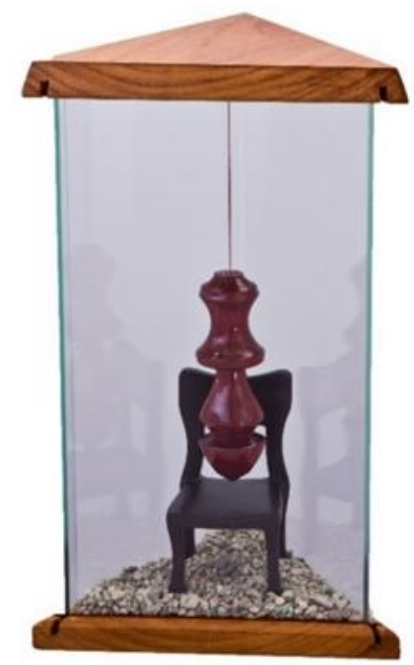

Fonte: Ernesto Ferro, 2013.

Ao criar, ele brinca de retirar do cotidiano objetos triviais, realocando-os até que tomem outro sentido e chamem a atenção para aspectos que antes não mais saltavam aos olhos, já que se tornaram corriqueiros e naturalizados. A provocação está na quebra de definição concreta, na possibilidade de ler de outra maneira e ultrapassar os significados. A potência das obras está em que cada pessoa as pode ler de uma maneira, porque são provocadoras de indagações sobre a vida humana. Em diálogo com Ernesto durante os momentos de bate-papo, as/os estudantes da Pedagogia revelaram que, a partir de seus pontos de vista particulares, fazem a mesma obra ter múltiplas interpretações, ao mesmo tempo em que se mostraram capazes de se afastar de seus referenciais para se encantar com outros olhares sobre seu trabalho.

\section{Como é feita a expedição artística?}

Desde 2013, levei cerca de 300 estudantes de Pedagogia à galeria/ateliê de Ernesto Ferro, no contexto da disciplina Metodologia do Ensino de Arte. A 


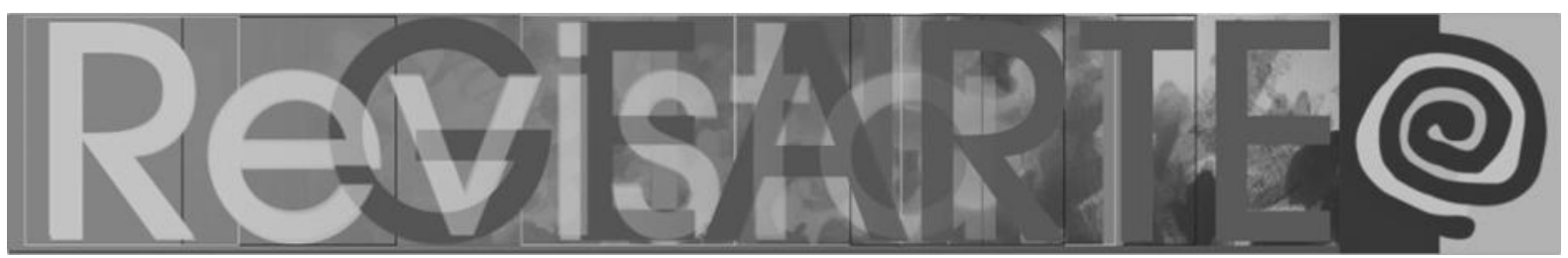

expedição é realizada em três etapas em tempos diferentes, mas interligadas, da seguinte forma:

- pré-campo: visita da professora regente ao artista e contextualização em sala de aula;

- campo: visita do grupo, com apreciação do acervo de obras, bate-papo com o artista e oficina;

- pós-campo: reflexões sobre a expedição, rodas de conversa, escritura de relatos, criação de portfolios.

\section{Pré-campo: visita ao artista e contextualização em sala de aula}

O pré-campo é uma ida à galeria que faço sozinha, antes do início das aulas, em todo semestre letivo. Apesar de fazermos a expedição desde 2013, em todos os oferecimentos da disciplina de Arte, o pré-campo é fundamental para que possamos conversar sobre os propósitos da ação, questionar com curiosidade o que fazemos, a fim de não repetir um procedimento sem indagá-lo. Os objetivos de levar estudantes de Pedagogia ao ateliê são inicialmente conhecidos, mas o tempo e as experiências anteriores os renovam, modificam e enriquecem. No précampo, fazemos novos combinados e eu aprecio as obras do acervo que estão no espaço, já que, além de Ernesto produzir constantemente novas peças, muitas delas não ficam na galeria por estarem expostas em outros locais. É um momento de abertura para reflexões e transformações, que nos permite repensar a preparação do projeto como um todo, outros possíveis percursos na galeria, novos materiais para a oficina, outras construções e referências teóricas que fundamentem a formação artística das pedagogas, novas conexões que podem ser estabelecidas.

A contextualização feita nas aulas anteriores à visita conta com procedimentos de mediação que têm variado e se transformado, consistindo, de modo geral, em estudos sobre nossas compreensões de Educação e de Arte, 


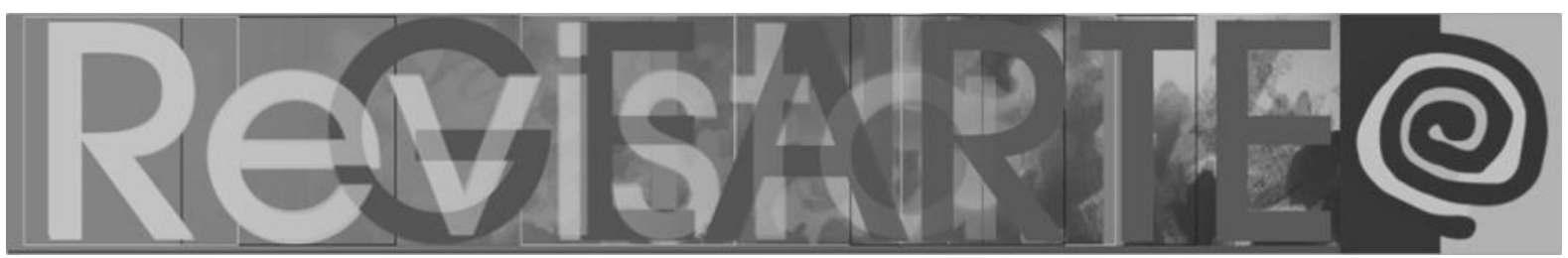

sobre os eixos de aprendizagem da abordagem triangular de Ana Mae Barbosa, sobre o ensino de Arte voltado às crianças e uma aula especialmente sobre Ernesto Ferro e sua produção, imediatamente anterior à visita, com base em um amplo material de textos e imagens sobre as obras do artista. Além disso, também em momentos de nutrição estética, com apreciações de outros/as artistas (das várias linguagens), exercitando olhares e emergindo diálogos. Pensar em mediar a ida ao ateliê significa considerar, segundo Arnheim (2002), que o contato com obras pode não ser suficiente para que as pessoas as percebam sensivelmente e possam analisá-las, sendo que o olhar deve ser despertado e trabalhado.

Um dos debates propostos na disciplina de Arte, sobre as ações pedagógicas naturalizadas em artes desenvolvidas nas instituições escolares no Brasil, contribui com o despertar dos olhares dos/das estudantes para quando vamos ao ateliê. Quando problematizamos as concepções de criança, de arte e de educação que norteiam as práticas pedagógicas nas escolas, quando questionamos os condicionamentos culturais promovidos pelos meios de comunicação e as corporações de entretenimento, que acabam se tornando as principais referências de crianças, adolescentes e jovens hoje, nos preparamos para uma visão de outras referências. Susana Rangel Vieira da Cunha (2017, 2019), que trata das proximidades da arte contemporânea com o trabalho pedagógico na Educação Infantil, afirma que todos nós estruturamos, nos anos iniciais de nossas vidas, o pensamento simbólico-poético, similar aos dos artistas, porém a maioria das pessoas desiste de transformar a obviedade do cotidiano, devido a fatores sociais, culturais e econômicos que estancam as possibilidades de ressignificar o que está no mundo e singularizar ações, pensamentos e modos de ser.

\section{Ateliê aberto, entramos na selva do artista: apreciação, bate-papo e oficina}

Meu acompanhamento no dia da visita é o de mediadora do encontro, observadora que registra e, em certos momentos, também dialoga e cria. 


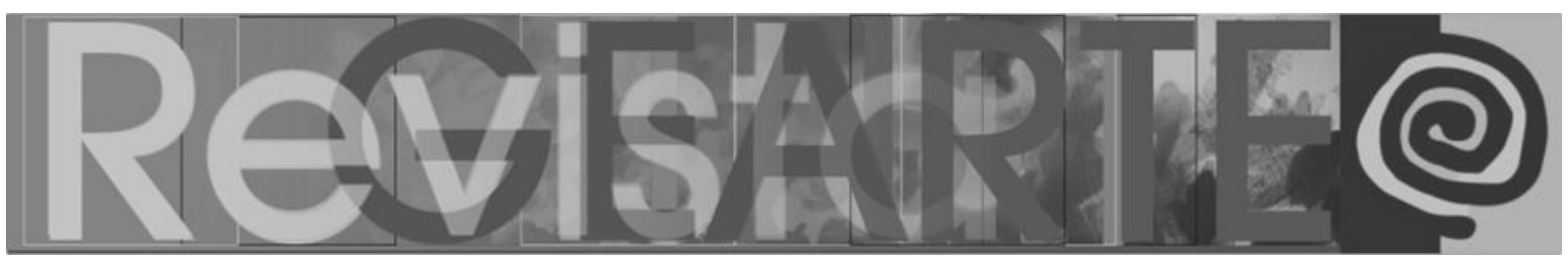

Ao chegarem ao ateliê, as/os estudantes caminham pelo espaço realizando a apreciação das obras. Essa etapa dura cerca de uma hora. Desde a primeira realização até a que ocorreu em 2019 (quando fizemos uma descontinuação, considerando a suspensão das atividades presenciais por tempo indeterminado devido à pandemia ocasionada pelo novo coronavírus), todas as pessoas declararam se sentir muito bem-vindas, apesar de para muitas, à primeira vista, o ambiente parecer bastante diferente, por nunca terem ido a um museu ou galeria.

Ao adentrar, seus ritmos interno e externo começam a se modificar. Elas caminham com cautela, curiosidade e, frequentemente, expressando surpresa, como se estivessem, conforme avançam por entre as obras, tornando a unir e enredar o que estava esparso em si: pensamentos, presença física, sensações e sentimentos. A cisão comum entre corpo e mente, razão e emoção produzida pelo sistema e pelo cotidiano parece ir sendo rompida. Ver, sentir e conhecer retomam estreita ligação. Não é solicitado que não conversem; contudo, em todas as ocasiões em que a visita foi feita, a palavra desapareceu durante essa primeira hora. O ritmo dos movimentos observados é lento e temos silêncio.

Ponderando que seja fundamental para o desempenho da profissão docente a atitude de escuta, Luciana Ostetto (2018) contribui com a compreensão do valor do silêncio. Essa autora afirma que um tema muito presente, na atualidade, no âmbito da educação de crianças, é a necessidade da escuta das mil e uma linguagens de que meninos e meninas lançam mão para se relacionarem com o mundo e constituírem sentidos, para se apropriarem de significados e expressarem o que vão conhecendo, na aventura que se abre cotidianamente como novidade ao mundo. Nesse sentido, ela afirma que estar com as crianças é disponibilizar-se a adentrar nos seus mundos. Só cultivando o silêncio cultivamos a escuta atenta e cuidadosa das crianças, podendo encontrar uma forma de realmente enxergá-las e conhecê-las. Ostetto (2018, p. 52-53) afirma que silenciar, calar-se é a atitude que abre caminho para a escuta e indaga sobre quem ensina o/a professor/a a escutar: 


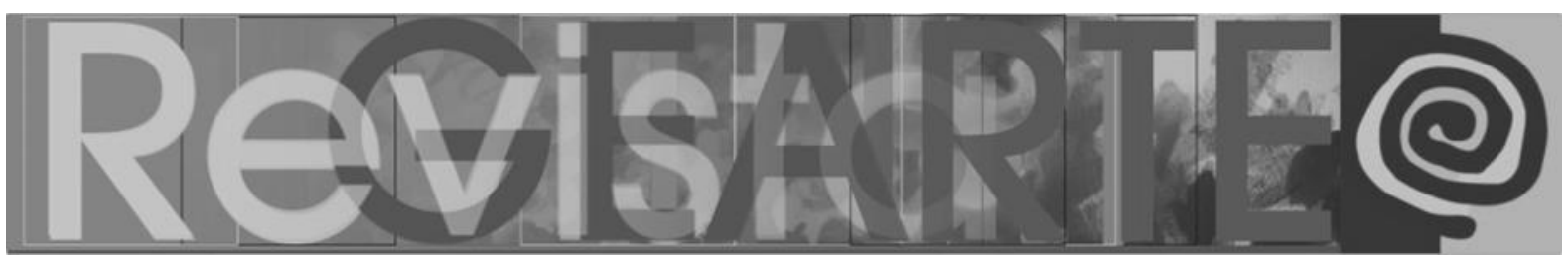

No caso dos professores, para escutar a criança que se esconde no aluno, as diferenças presentes na pretensa homogeneidade da sala de aula, da escola. O exercício de dar oportunidade para o silêncio, cultivando o encontro consigo mesmo, apresenta-se como um ingrediente essencial na formação do educador. O movimento de ouvir a si mesmo no silêncio, abrindo espaço para perceber-se, projeta a possibilidade de aprender a ouvir e ver o outro, os outros, o mundo alargado pela experiência. É necessário aprender a escutar. Mas, quem ensina? Onde há, na experiência cotidiana e formativa, o pedido de silêncio como tempo oportuno para fertilizar a escuta?

Num segundo momento, realizamos o bate-papo com o artista. Quando é aberto o diálogo, as palavras são retomadas aos poucos, como afeto e curiosidade. Ernesto não prepara nenhuma apresentação formal e permanece aberto e curioso, a cada encontro, para as perguntas que trazem interesses amplos, conflitos, desejos, inquietações. Os/As estudantes surgem com questões relativas a vivências, formação, memórias do artista, seus recursos criativos e processos, modos como se conectam seus pensamentos ao produzir as obras, curiosidades sobre as materialidades, entre outros detalhes que, muitas vezes, não observamos.

Com o passar dos anos, vamos somando descobertas sobre sua bagagem, conceitos e narrativas não explicitados por ele, no sentido de problematizar sua produção, conhecer suas ideias, suas influências. Descobrimos, em cada ocasião, novas formas pelas quais sua manifestação artística se relaciona com processos científicos, sociais e políticos.

O momento de bate-papo com Ernesto Ferro aproxima a obra de arte da pessoa do artista e percebemos melhor que ela deixa de ser apenas um objeto de apreciação, mas que aglutina múltiplas formas de pensar e saber, que é fruto da experiência de vida do artista e, dialogando com ele, passamos a compartilhar sua criação como interpretantes ativos. O processo individual do artista se torna, necessariamente, coletivo. 


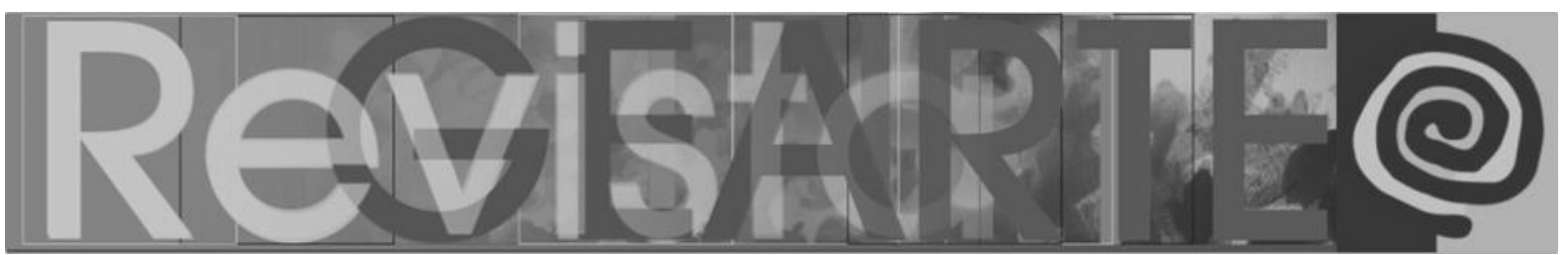

Figura 6 - Bate-papo com o artista

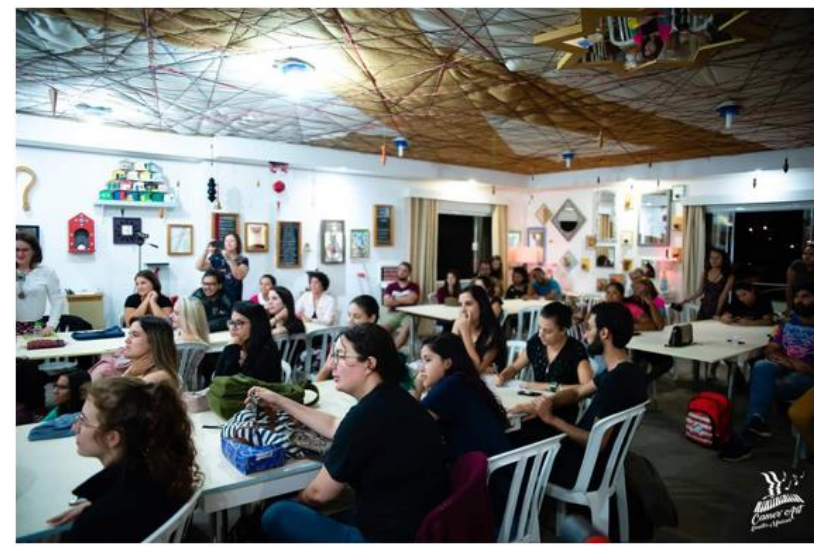

Fonte: Camer'Art, 2019.

Figura 7 - Bate-papo com o artista

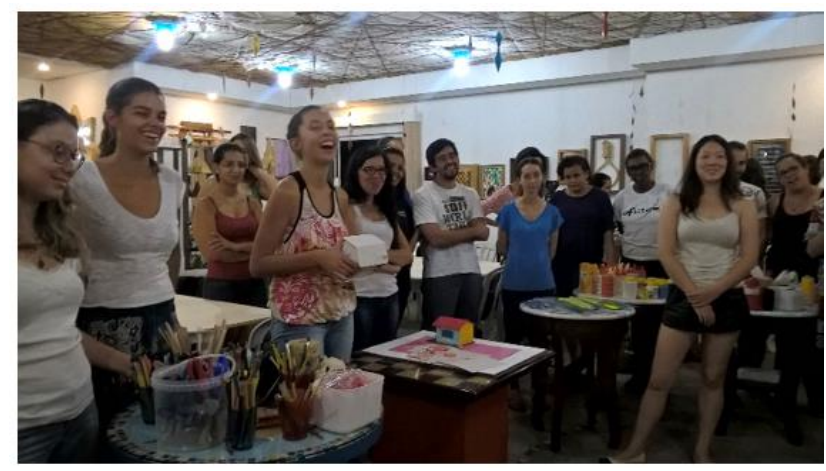

Fonte: Acervo da autora, 2019.

A terceira etapa do encontro envolve a oficina de criação com os materiais ofertados por Ernesto Ferro, que causam entusiasmo, alegria, por vezes misturados a certo estranhamento e novidade diante dos materiais. Ele propõe como suporte principal a madeira, mas somada à utilização de outras materialidades para as criações. Muitos tipos e formatos de madeira, rochas de variadas texturas, papéis, serragens que tinge de todas as cores, tintas, canetas, pincéis, tesouras, fitas adesivas, colas, vidros, tecidos, fios, barbantes, canos de papelão, ferramentas como serras, serrotes, lixas, medeiam descobertas. Ao produzir arte em seu ateliê, os/as estudantes têm manifestado, primeiramente, o desejo de oferecer outros objetos não estruturados às crianças, por perceberem que 0 desafio desses materiais expande a imaginação e possibilita a criação de novas representações. Em seguida, fazem analogias entre os modos de produzir 


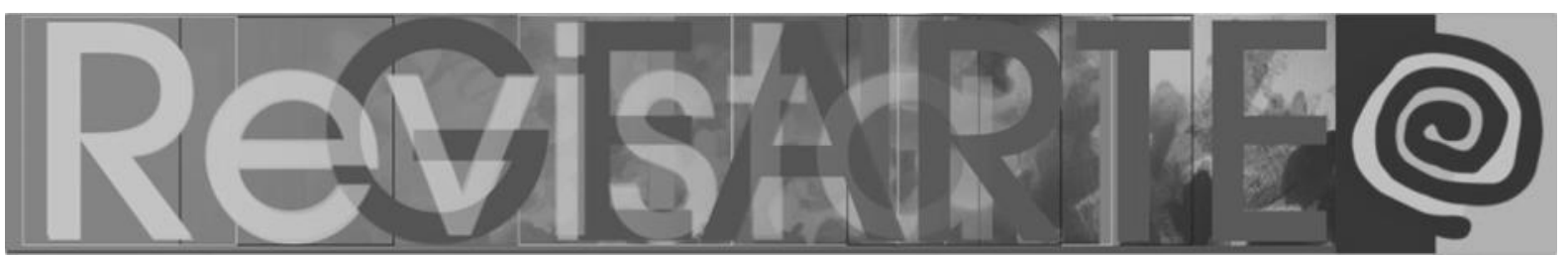

em arte contemporânea e as demandas das crianças pequenas, pois ambos se baseiam em uma postura exploratória, muitas vezes proibida pela escola.

Figura 8 - Oficinas

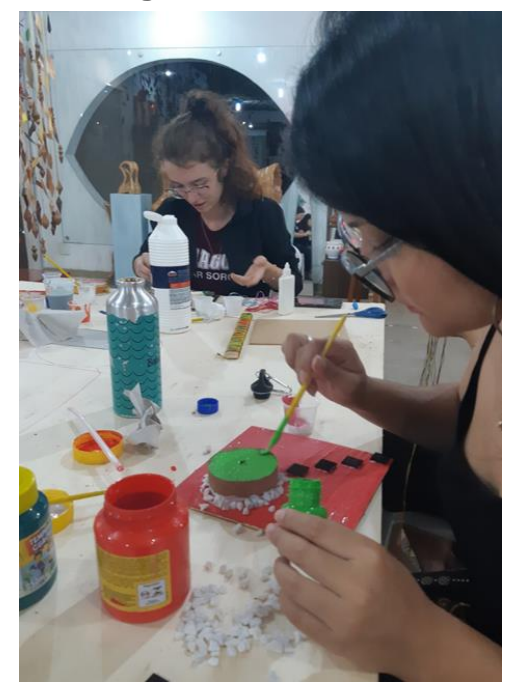

Fonte: Acervo da autora, 2019.

Figura 9 - Oficinas

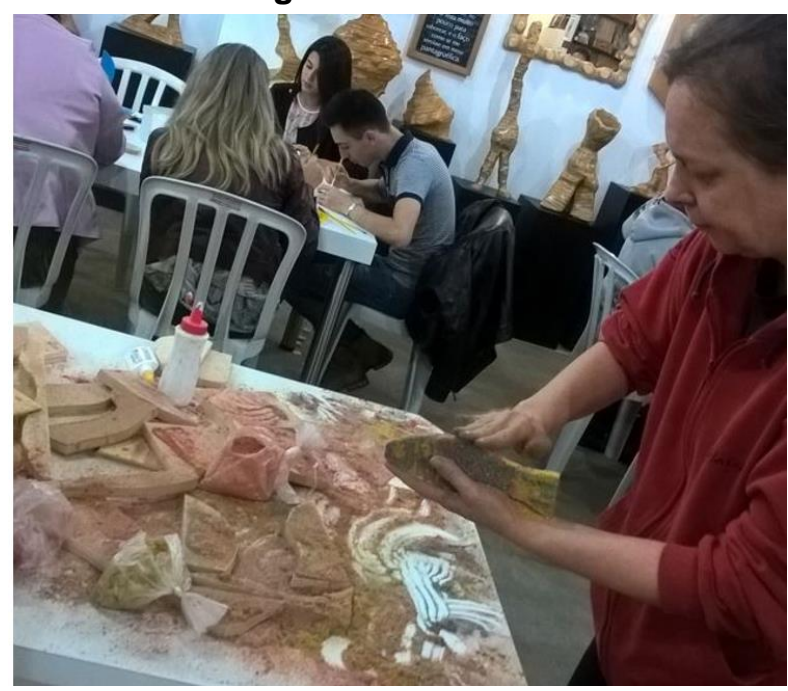

Fonte: Acervo da autora, 2019.

$\mathrm{Na}$ oficina, gestos aleatórios e ritmados produzem traçados, montam esculturas, fazem melecas, espalham tinta, cola, serragem, elaboram formas com pastilhas, rochas, papéis. Os/As estudantes vão mudando de uma disposição reflexiva para o gesto brincante, soltando movimentos que recuperam a disposição da criança arteira. 


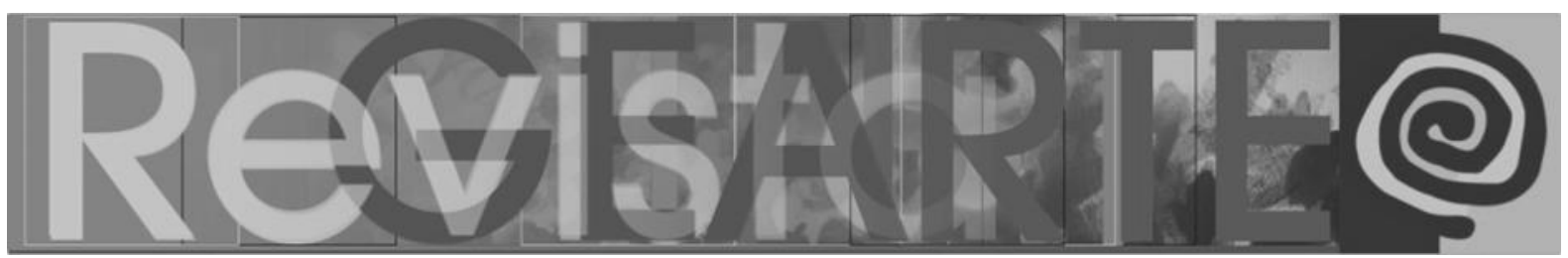

Ernesto Ferro não interfere no sentido de indicar "o que deveria ser feito" e, surpreendentemente, ao contrário do que costuma acontecer dentro da universidade, nenhum/a estudante pergunta "o que é pra fazer?". Todos/as se levantam e se dirigem aos materiais com arrebatamento, mas com calma. Apesar de demonstrarem entusiasmo e alegria com a grande variedade dos materiais, parecem escolher sem cobiça ou ansiedade, mas sim com estratégia. Olhares muito vivos, presentes e brilhantes. Presencio a concessão da liberdade de escolha por parte do artista, bem como a atitude de saboreá-la com tranquilidade por parte dos/das estudantes, que selecionam uma coisa e outra com esmero e serenidade.

Novamente, a palavra falada vai sendo substituída pela experimentação do gesto que desafia o raciocínio. Os/As estudantes exploram os materiais com confiança e sem fazer perguntas verbais. Seus questionamentos e sentimentos de não saber se transportam para o fazer das mãos, que criam diferentes formas e texturas.

\title{
O que profissionais da Educação aprendem em expedição ao espaço de trabalho do artista contemporâneo?
}

No pós-campo, ao retornarmos às aulas na universidade, fazemos avaliações e reflexões sobre a expedição, com base em apreciação das instigantes fotografias feitas pelas/os estudantes durante a visita. Rodas de conversa, relatos por escrito e criações imagéticas são anexadas a seus portfólios. Por meio das reflexões dos/das estudantes, observa-se que a entrada no ateliê parece fazer relembrar a surpresa primordial de entrar no mundo, ver-se, rever-se. Heitor Henrique Faustino ${ }^{3}$, escreveu em abril de 2019:

\begin{abstract}
A visita à galeria do Ernesto Ferro me despertou muitos sentimentos e questionamentos, um deles diz respeito à forma como observamos e compreendemos as coisas que estão à nossa volta, sejam elas um objeto, uma pessoa ou uma relação, tudo exige uma perspectiva de observação, muda-se a perspectiva, muda-se também a compreensão sobre o objeto e a atitude diante dele. A cadeira fragmentada e pendurada no teto me levou a pensar sobre a forma como venho conduzindo alguns aspectos de minha
\end{abstract}




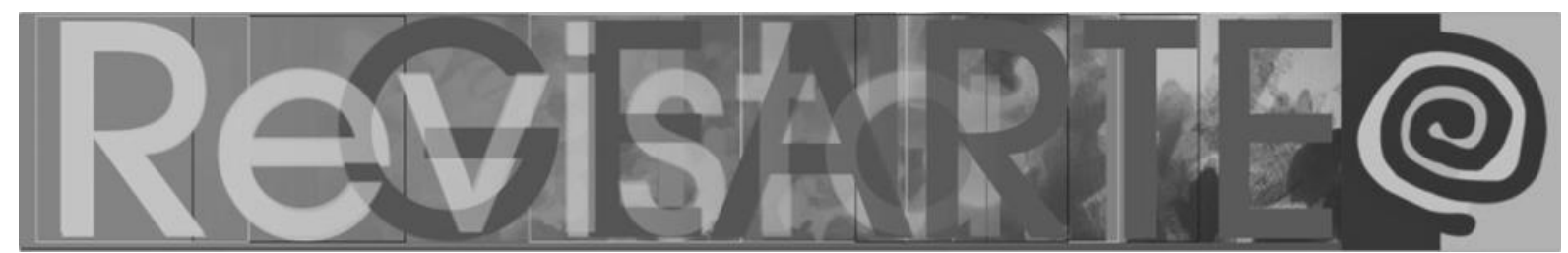

vida, e que se eu quiser transformações, faz-se preciso mudar de perspectiva, mesmo este não sendo um processo nada fácil. Como Alice que caiu em um buraco e se viu diante daquilo que se pode chamar de "loucura", talvez nós também precisemos mergulhar nesse universo invertido, que nos faz questionar o já dito e vivido, e emergir transformados.

Figura 9 - Ernesto Ferro nos retribui a visita. Exposição Portfólios da Pedagogia
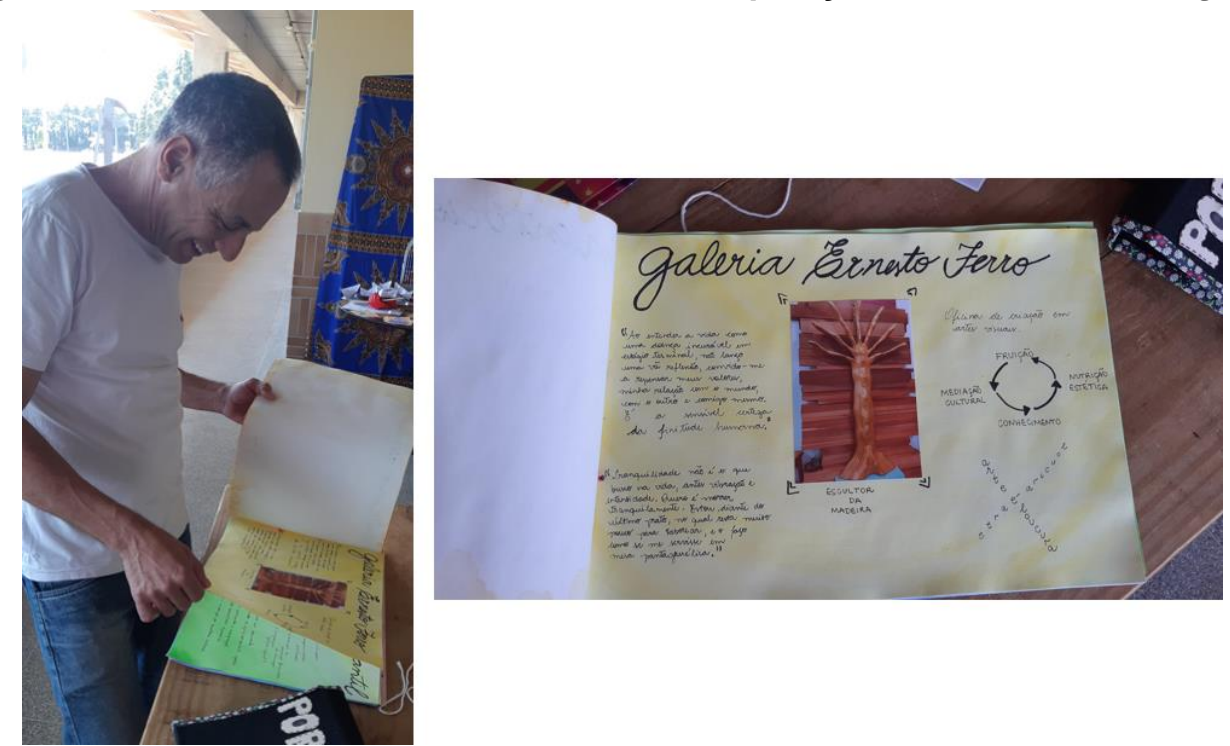

Fonte: Acervo da autora, 2019.

Por ocasião da exposição Portfólios da Pedagogia, em 31/08/2019, no evento Universidade Aberta (que recebe, no final de semana, pessoas da comunidade externa, de todas as idades e de diversas cidades do entorno para que possam conhecer o campus e tudo o que ele oferece), convidamos Ernesto Ferro para ver nossos trabalhos na universidade e, ao aceitar, ele nos retribuiu a visita. Apreciou os portfolios e se surpreendeu ao encontrar neles muitos registros sobre seu trabalho, tal como no portfólio de Paula Bologna (figuras 8 e 9). Paula Bologna ${ }^{4}$, em meio às profundas reflexões registradas em seu portfólio de 2018, expressa os impactos da expedição, também "convidando-se a repensar seus valores, sua relação com o mundo, com o outro e consigo mesma". Para os/as estudantes do curso de Pedagogia, com frequência, a ida ao ateliê é "a coisa preferida" e, diante disso, aprofundam suas razões. Zilda Maria de Lara ${ }^{5}$ relatou em 2015: 


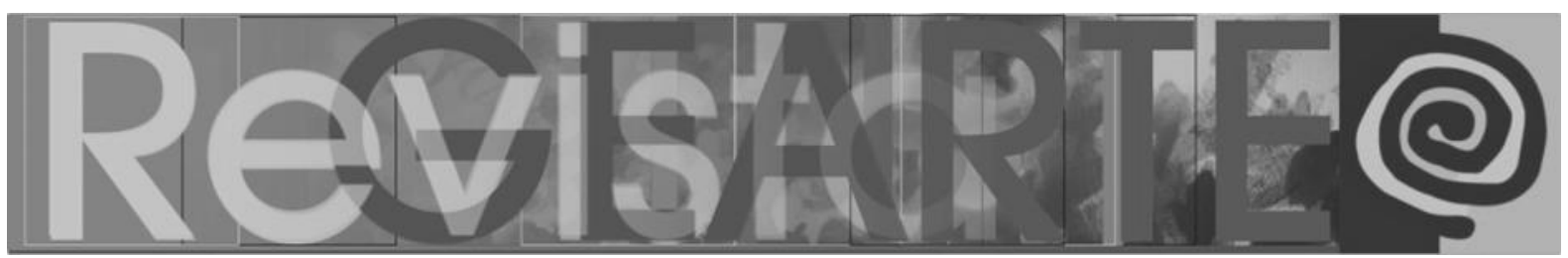

Quando a gente entra e vê o modo como ele organiza o espaço e com que escolhas ele agrupa aquilo que ele expõe, entende que o modo como ele expõe, mostra critérios de organização do acervo, o que ele quer mostrar está exposto ali. Há coisas que ele possivelmente não quis expor. E não estão ali. [...] quando ele fala sobre cada objeto eu percebi o quanto nós não sabemos valorizar o ofício do artista. O uso da luz me chamou atenção. A escolha de quais objetos devem ficar sob o foco de qual luz. O distanciamento, os agrupamentos. O que ele deixa ao alcance da mão, o que ele coloca mais longe, o que ele deixa mais para acima do nosso olhar, o que ele coloca abaixo do olhar. Como ele escolhe cores, como as formas são escolhidas por ele para dizer algo e como ele relaciona essas cores e essas formas para falar daquilo que ele fez. Como ele apresenta as peças e as imagens, as incidências de luz, as composições de um ou mais objetos. Como ele faz a ocupação do espaço que vai receber a interferência de outras pessoas. Fiquei pensando que quando ele nos oferece a oportunidade de nós - um bando de crianças grandes - entrarmos e intervirmos num ambiente que é dele, onde ficam as obras dele e representam momentos e histórias de sua vida, nós podemos entender sentimentos que ele teve, coisas que ele queria dizer, mas não teve oportunidade de expressar. Imagens que não foram compreendidas e ele queria comunicar. Estar no ateliê do Ernesto Ferro, estar com a pessoa dele e não só com os objetos de arte que ele produz, fez com que eu percebesse o ser humano por trás da arte. Interagir com o Ernesto, ver as obras, usar os materiais dele, pegar nas minhas mãos recursos que ele cedeu e fazer uma obra, me fez pensar sobre o cuidado e o apreço que se deve ter em comunicar a arte, porque ela vem com posição política, com escolhas, com perigo de ser mal compreendido. [...] Me fez pensar sobre 0 quanto nós projetamos nos objetos quem nós somos, vemos a representação de quem somos nós e de como cuidamos ou descuidamos de nós mesmos e do outro. [...] Eu fiquei pensando se o que resultou da minha interferência, do que eu senti e produzi lá através dos meus sentimentos, passou a fazer parte do acervo de coisas que compõem o ateliê daquele homem. Eu sou contadora de histórias e, tal como quando eu conto uma história e deixo de ser a mesma pessoa, por causa do contato com a história e com quem a ouviu, tal como o observador diante de um quadro que não é mais o mesmo de antes, fico pensando se o ateliê também foi modificado porque a gente interferiu ali... eu não sei mensurar se isso produziu algo no delicado coração do Ernesto.

A partir do acompanhamento das oficinas e das quase trezentas esculturas criadas pelos/as estudantes dentro do ateliê, da escuta e da leitura de suas reflexões/registros escritos, verificou-se que a proposta de fazer arte em um ateliê apropriado, que conta com suportes, materiais e instrumentos variados, com a mediação de um artista externo à universidade, tem propiciado uma libertação mais incisiva das concepções de arte que se enquadram no senso comum e nos processos tradicionais de escolarização. Os/As estudantes relatam que o ambiente físico do ateliê altera sua disposição para criar. De acordo com eles/elas, as 


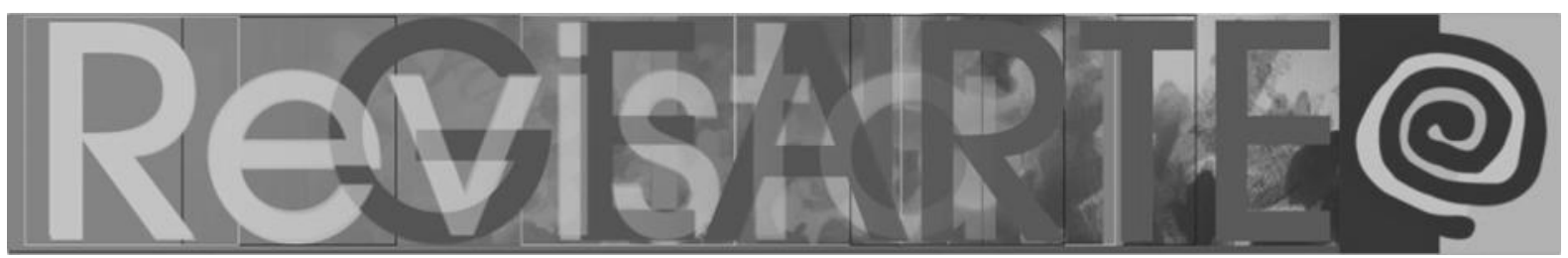

paredes, o teto e o chão fartos de obras, objetos pendurados, coleções, memórias e narrativas, afastam as distrações do mundo exterior e intensificam os desejos criativos.

Se a intenção com a expedição é a de nutrir esteticamente, possibilitando às/aos estudantes não somente a ampliação de repertórios, mas também a construção de inspirações para ações com crianças que se aproximem da arte produzida no tempo presente, penso, a partir dessa fala, que a entrada no ateliê e a experiência de fruir que ela representa possa contribuir com a reflexão sobre determinadas formas de ver as coisas. Comumente, nosso olhar treinado pela lógica do consumo nos faz estacionar em um modo não crítico de olhar, produzindo uma ideia de que "pensamos ver". Apreciar as obras e poder conversar com o artista sobre elas ajuda a redescobrir um modo de "ver" para além de aspectos aparentes de forma imediata na construção da representação.

Apreciar arte entrelaça-se à formação de professores/as quando se percebe que os artefatos da cultura visual são carregados de valores e comunicam ideias e que, como mediadores/as culturais, é preciso conhecer os elementos das artes, saber que ver acontece junto à capacidade de percepcionar, isto é, de interpretar, fazer conexões, rememorar. O aprendizado que construímos é um somatório de nossas memórias, experiências pregressas e do novo que se descobre, se analisa, se indaga.

A nutrição estética proposta pela expedição ao ateliê instiga a se exercitarem olhares interrogativos e a refletir sobre o processo de ver, de fruir, compreendendo-o como repleto de informações que interferem nas identidades, nos aprendizados. As expedições artísticas almejam contribuir para que a fruição seja viva e criativa, reconstrutora de ideias, ajudando-nos a reaprender a ver, atribuindo significados ao que vemos. Que no ato da percepção sejamos de fato capazes de fazer conexões, vendo os significados das coisas mediante o sentir e o pensar crítico. 


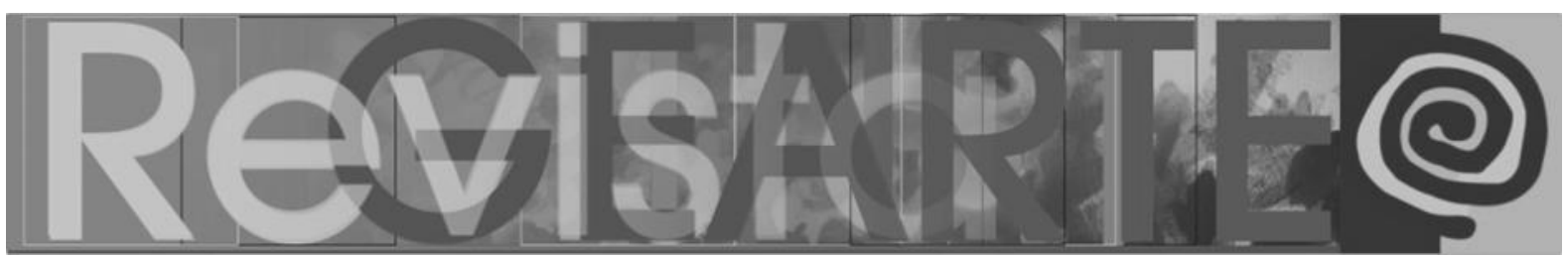

Da entrada no ateliê, emerge uma compreensão do processo de criação e de aprendizado do outro, fator desejável à prática docente em Arte, a fim de que se deixe de oscilar entre o diretivismo técnico (saber fazer) e o laissez-fare (exprimir livremente sem interferência da professora). Segundo Vieira da Cunha (2019), ambas as abordagens não oportunizam o conhecimento sobre a própria arte ou mesmo sobre o desenvolvimento do imaginário infantil, uma por considerar a criança como tábula rasa e a outra por considerá-la como portadora de potencialidades expressivas/criativas inatas.

No ateliê, os/as estudantes apreciam e interagem com as séries de obras do artista, conhecem suas técnicas e artifícios, escutam respostas às mais variadas questões, vão do olhar contemplativo à elaboração de discursos interpretativos sobre as obras expostas, criam composições escultóricas, mas algo mais acontece. Ao acontecer um encontro com a alteridade em uma paisagem desconhecida, estabelecem um outro tipo de relação com os artefatos, mas também, como relatam diversas/os estudantes, com suas próprias vidas.

Após as expedições, verifiquei que futuros/as pedagogos/as passaram a ter mais referências para planejar propostas em seus locais de trabalho, tomando as rédeas da criação pedagógica de modo a se atreverem, proporem fazeres artísticos com as crianças. Até então, o processo tem revelado contribuir para que se formem professores/as empáticos/as dos processos de aprendizagem das crianças, planejando ações provocadoras de descobertas e possibilitando às crianças o tempo e as condições para viverem as experiências.

A ação promove a aproximação entre futuros/as pedagogos/as e o artista, esperando descobrir o que brota do encontro que leva a conhecer não exclusivamente as obras, mas também a pessoa do artista. Aproximar quem aprecia de quem cria tem significado a possibilidade de ler a visão de mundo de quem se expressou, conhecer a particularidade do autor e ser um/a tradutor/a dessa visão. O procedimento inteiro no ateliê - de apreciar, conversar, fazer - cria 


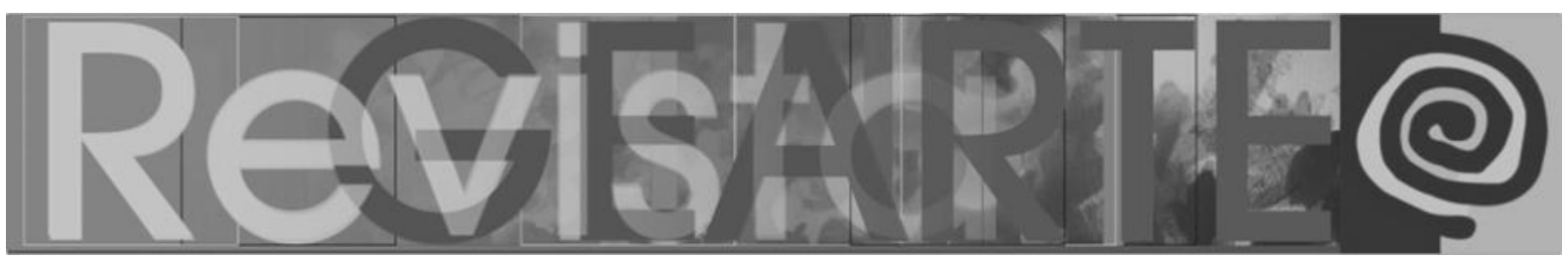

um tempo de formação docente dentro de um ambiente livre de julgamentos, bem como propicia um processo empático para com o artista, almejando descobrir a presença expressiva dos elementos da sua linguagem plástica, das suas representações do humano.

Junqueira e Gomes (2009, p. 2073) afirmam que os ateliês abertos hoje fomentam experiências híbridas, a partir de um conceito de ateliê como interface que o definiria "não mais como espaço 'entre' artista e público, mas sim como lugar habitado e construído por ambos". Mediante essa afirmação, sustentamos o pensamento de que, para profissionais da Educação, o ateliê tem representado um espaço de compartilhamento de arte, ampliação de repertório, surpresa e aprendizado. E provocamos o artista a nos responder a mais essa pergunta, elaborada pelo desejo por aprender de Zilda Lara: o ateliê também foi modificado porque a gente interferiu aí? Nós também produzimos algo no seu delicado coração de artista?

Observo a importância das expedições artísticas ao ateliê do artista contemporâneo como cumprindo uma função da Arte na educação, tal como a menciona Susana Vieira da Cunha (2019): de provocar questionamentos e desencadear outra educação do olhar, que rompa com o estabelecido, com as convenções irrefletidas sobre o mundo. Que faça com que as pessoas continuem buscando e dando sentido poético à vida.

As rotas e os instrumentos utilizados para realizar esse tipo de ação continuarão a ser redefinidos no próprio caminhar. A iniciativa de criar laços entre a universidade e 0 ateliê do artista precisa ser amadurecida em termos pedagógicos, institucionais e estratégicos de sustentabilidade. A riqueza de possibilidades desse encontro no cenário atual aponta para o desenvolvimento da proposta, e continuaremos a refletir para melhorar a ação. Até o momento, entretanto, já temos amplos indicativos do quanto a expedição criativa ao ateliê do 


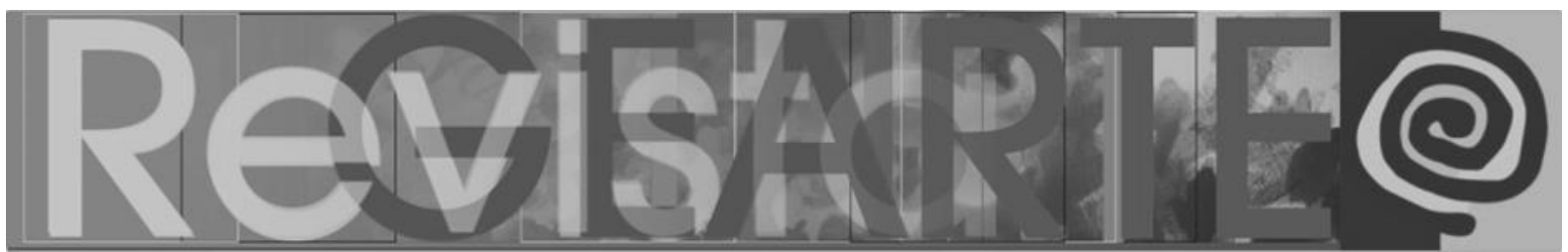

artista contemporâneo pode contribuir com o campo da formação de professores/as.

\section{Notas}

1 A palavra Arte é grafada com letra inicial maiúscula quando é feita referência ao campo de conhecimento e em letra inicial minúscula para tratar da arte como expressão pessoal ou coletiva e manifestação cultural de uma sociedade.

2 Entrevista de Ernesto Ferro concedida a Lucia Lombardi, em março de 2014.

3 Heitor Henrique Faustino, Paula Bologna e Zilda Maria de Lara são egressos do curso de Pedagogia que visitaram o ateliê de Ernesto Ferro nos dias 17/04/2019 e 19/05/2015 e autorizaram o uso de suas falas e das imagens de seus portfólios.

4 Idem.

5 Idem.

\section{Referências}

ARNHEIM, Rudolf. Arte e Percepção Visual. São Paulo: Nova Versão, 2002.

BARBOSA, Ana Mae. A imagem no ensino da arte: anos 80 e novos tempos. 1. ed. São Paulo: Perspectiva, 1991.

BARBOSA, Ana Mae (org.). Inquietações e mudanças no ensino da Arte. São Paulo: Cortez, 2002.

BARBOSA, Ana Mae. Tópicos utópicos. Belo Horizonte: C/ Arte, 1998.

BRASIL. Ministério da Educação. Secretaria de Educação Básica. Diretrizes curriculares nacionais para a Educação Infantil / Secretaria de Educação Básica. Brasília: MEC; SEB, 2010. Disponível em: http://portal.mec.gov.br/component/content/article?id=12579:educacao-infantil. Acesso em: 21 set. 2012.

BRASIL. Resolução do CNE/CP № 1, de 15 de maio de 2006. Institui Diretrizes Curriculares Nacionais para o Curso de Graduação em Pedagogia, licenciatura. Diário Oficial da União, Brasília, 16 maio 2006. Disponível em: http://portal.mec.gov.br/cne/arquivos/pdf/rcp01_06.pdf. Acesso em: 20 jun. 2007.

DE LA BARRA, Pablo León. Espaços para a liberdade: por dentro do ateliê do artista. In: Germano, Beta. Espaços de trabalho de artistas latino-americanos. Fotografia Fran Parente. 1. ed. Rio de Janeiro: Cobogó, 2019. p. 12-17.

EGAS, Olga. As coisas escritas não vão ser mais importantes que as coisas desenhadas nas figuras: direitos de aprendizagem em arte. Educação em Foco, Juiz de Fora, Edição Especial, p. 119-132, fev. 2015,. Disponível em: https://periodicos.ufjf.br/index.php/edufoco/article/view/19673. Acesso em: 10 abr. 2021.

FARIA, Ana Lúcia Goulart de. A contribuição dos parques infantis de Mário de Andrade para a construção de uma pedagogia da educação infantil. Educação \& Sociedade, Campinas, ano XX, n. 69, p. 60-91, dez. 1999.

FARIA, Ana Lúcia Goulart de; MACEDO, Elina Elias de; SANTOS, Solange Estanislau dos. Educação Infantil e diversidade cultural: para uma pedagogia macunaímica. In: ABRAMOWICZ, Anete; VANDERBROECK, Michel (org.). Educação Infantil e diferença. Campinas: Papirus, 2013. p. $49-70$. 


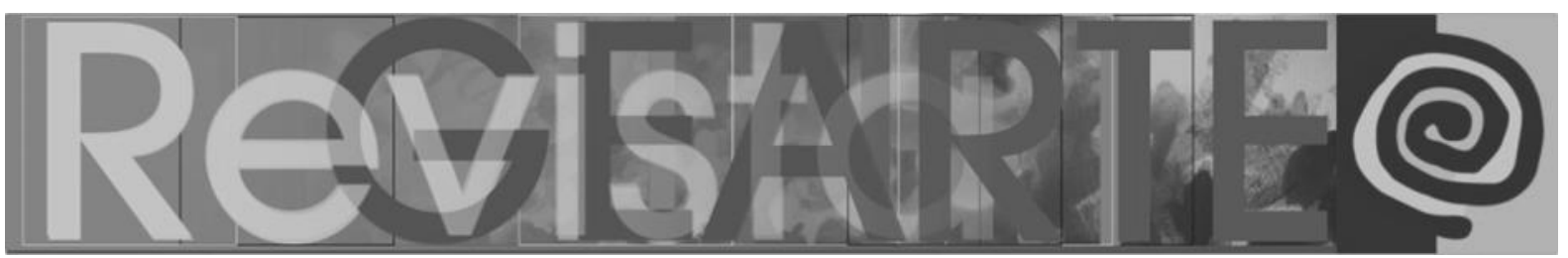

FERRO, Ernesto. Instante Reflexo. Rio de Janeiro: Ed. Livre Expressão, 2013.

GERMANO, Beta. Espaços de trabalho de artistas latino-americanos. Fotografia: Fran Parente. 1. ed. Rio de Janeiro: Cobogó, 2019.

IMBERNÓN, Francisco. La formación del profesorado. Barcelona: Paidós, 1997.

JUNQUEIRA, Lilian Maus; GOMES, James Zortéa. O ateliê aberto como interface da produção artística em esfera pública: experiências do Atelier SubterrÂnea. In: ENCONTRO DA ASSOCIAÇÃO NACIONAL DE PESQUISADORES EM ARTES PLÁSTICAS - TRANSVERSALIDADES NAS ARTES VISUAIS, 18, 2009, Salvador. Anais [...]. Salvador: Programa de Pós-Graduação em Artes Visuais da Universidade Federal da Bahia, 2009. v. 1. p. 2068-2082.

LOMBARDI, Lucia Maria Salgado dos Santos. Formação corporal de professoras de bebês: contribuições da Pedagogia do Teatro. 2011. Tese (Doutorado em Educação) - Faculdade de Educação, Universidade de São Paulo, São Paulo, 2011. Disponível em: https://teses.usp.br/teses/disponiveis/48/48134/tde-21072011-103922/pt-br.php. Acesso em: 10 abr. 2021.

LOMBARDI, Lucia Maria Salgado dos Santos. Teatro no curso de Pedagogia: concepções e mediação cultural. Teatro: criação e construção de conhecimento, v. 5, n. 2, 2017, p. 33-44. Disponível em: https://sistemas.uft.edu.br/periodicos/index.php/teatro3c/issue/view/116. Acesso em: 10 abr. 2021.

MACEDO, Elina Elias de; SANTIAGO, Flávio Santiago; SANTOS, Solange Estanislau dos; FARIA, Ana Lúcia Goulart de. Infâncias e descolonização: desafios para uma educação emancipatória. Crítica Educativa, Sorocaba, v. 2, n. 2, p. 38-50, jul./dez. 2016.

MARTINS, Mirian Celeste; AMERICANO, Renata Queiroz de Moares. Nutrição estética: por uma didática poética na formação do professor. In: GUIMARAES, L. REGO, L. (org.). Ações políticas de/para enfrentamentos, resistências e recriações [recurso eletrônico]: Anais [do] XXVIII Congresso Nacional da Federação de Arte/Educadores do Brasil [e] VI Congresso Internacional dos Arte/Educadores. Brasília, DF, 2018. p. 2751-2763. ISSN: 2525-880X.

MARTINS, Mirian Celeste; LOMBARDI, Lucia Maria Salgado dos Santos. Arte contemporânea no curso de Pedagogia. In: In: GUIMARAES, L. REGO, L. (org.). Ações políticas de/para enfrentamentos, resistências e recriações [recurso eletrônico]: Anais [do] XXVIII Congresso Nacional da Federação de Arte/Educadores do Brasil [e] VI Congresso Internacional dos Arte/Educadores. Brasília, DF, 2018. p. 2736-2749. ISSN: 2525-880X.

MARTINS, Mirian Celeste; LOMBARDI, Lucia Maria Salgado dos Santos. Ensino de Arte no curso de Pedagogia: travessia e perigo. In: CONGRESSO NACIONAL DA FEDERAÇÃO DE ARTE/EDUCADORES DO BRASIL, 27. Anais [...]. Campo Grande, 2017. p. 1944-1955.

NUNES, Kamilla. Espaços autônomos de arte contemporânea. Rio de Janeiro: Editora Circuito, 2013.

OLIVEIRA-FORMOSINHO. Julia. Pedagogia(s) da Infância: reconstruindo uma práxis de participação. In: OLIVEIRA-FORMOSINHO, Julia; KISHIMOTO, Tizuko Morchida; PINAZZA, Mônica Appezzato (ed.). Pedagogia(s) da infância: dialogando com o passado, construindo o futuro. Porto Alegre: Grupo A, 2007.

OSTETTO, Luciana Esmeralda. É preciso manter as orelhas verdes: o silêncio e a escuta na educação. In: MARTINS, Mirian Celeste; BONCI, Estela; MOMOLI, Daniel (org.). Formação de educadores: modos de pensar e provocar encontros com a arte e mediação cultural. São Paulo: Terracota Editora, 2018. p. 48-64.

PIMENTEL, Lucia Gouvêa. Abordagem Triangular e as narrativas de si: autobiografia e aprendizagem em Arte. Revista GEARTE, Porto Alegre, v. 4, n. 2, p. 307-316, maio/ago. 2017. Disponível em: https://seer.ufrgs.br/gearte/article/view/71493. Acesso em: 10 abr. 2021.

LOMBARDI, Lucia Maria Salgado dos Santos. Estudantes de Pedagogia em 392 


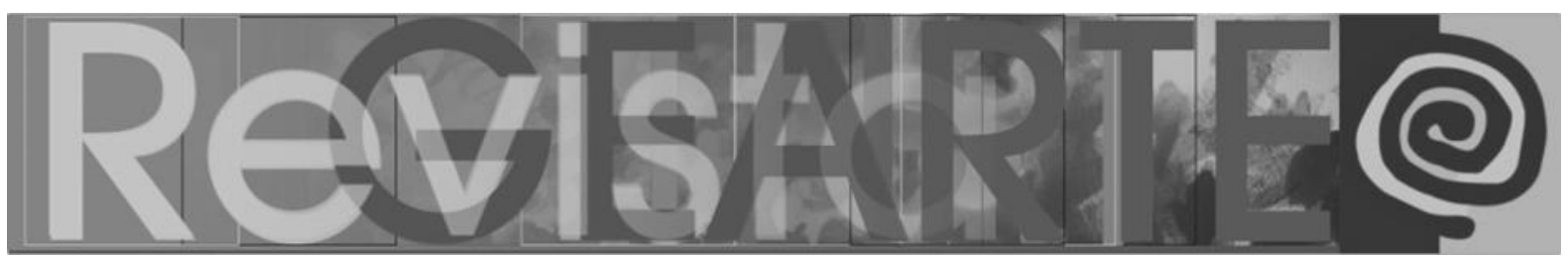

RICHTER, Sandra Regina Simonis; BARBOSA, Maria Carmen Silveira. Os bebês interrogam o currículo: as múltiplas linguagens na creche. Educação, Santa Maria, v. 35, n. 1, p. 85-96, jan./abr. 2010. Disponível em: https://periodicos.ufsm.br/reveducacao/article/view/1605. Acesso em: 10 abr. 2021.

RIZZI, Maria Christina de Souza Lima. Reflexões sobre a abordagem triangular do ensino da Arte. In: BARBOSA, Ana Mae (org.). Ensino da arte: memória e história. São Paulo: Perspectiva, 2008. p. 335-348.

RIZZI, Maria Christina de Souza Lima; SILVA, Mauricio da. Abordagem Triangular do ensino das artes e culturas visuais: uma teoria complexa em permanente construção para uma constante resposta ao contemporâneo. Revista GEARTE, Porto Alegre, v. 4, n. 2, p. 220-230, maio/ago. 2017. Disponível em: https://seer.ufrgs.br/gearte/article/view/71934/43524. Acesso em: 10 abr. 2021.

SACRISTÁN, José Gimeno. Poderes instáveis em educação. Porto Alegre: Artes Médicas, 1999.

TICOULAT, Fernando. A residência artística como um espaço de trabalho contemporâneo. In: GERMANO, Beta. Espaços de trabalho de artistas latino-americanos. Fotografia: Fran Parente. 1. ed. Rio de Janeiro: Cobogó, 2019. p. 25-30.

VIEIRA DA CUNHA, Susana Rangel. Como vai a Arte na Educação Infantil? Revista Apotheke, Florianópolis, v. 5, n. 3, ano 5, p. 10-24, dez. 2019.

VIEIRA DA CUNHA, Susana Rangel. Uma arte do nosso tempo para as crianças de hoje. In: CUNHA, Susana Rangel Vieira; CARVALHO, Rodrigo Saballa de (org.). Arte contemporânea e Educação Infantil: crianças observando, descobrindo e criando. Porto Alegre: Mediação, 2017. p. 9-26.

\section{Lucia Maria Salgado dos Santos Lombardi}

Professora do Curso de Pedagogia da Universidade Federal de São Carlos/Campus Sorocaba, onde lidera o GIAPE - Grupo de Pesquisa sobre Infância, Arte, Práticas Educativas e Psicossociais. Vice-líder do GPAP - Grupo de Pesquisa Arte na Pedagogia. Membro do Fórum de Educação Infantil de Sorocaba e Região. Mestre e doutora em Educação pela Faculdade de Educação/USP.

ORCID: http://orcid.org/0000-0001-6978-864X

E-mail: lucialombar-diufscar@gmail.com

Currículo: http://lattes.cnpq.br/5697508831302188

Recebido em 21 de fevereiro de 2021 Aceito em 12 de abril de 2021 